https://helda.helsinki.fi

Seismic Events in 2014-2016 around the Karelian Isthmus and Their Nature

Assinovskaya, B. A.

2019-01

Assinovskaya , B A , Gabsatarova , I P , Panas , N M \& Uski , M 2019 , ' Seismic Events in 2014-2016 around the Karelian Isthmus and Their Nature ', Seismic Instruments , vol. 55 , no. 1 , pp. 24-40 . https://doi.org/10.3103/S074792391901002X

http://hdl.handle.net/10138/314825

https://doi.org/10.3103/S074792391901002X

acceptedVersion

Downloaded from Helda, University of Helsinki institutional repository.

This is an electronic reprint of the original article.

This reprint may differ from the original in pagination and typographic detail.

Please cite the original version. 


\title{
Seismic Events in 2014-2016 around the Karelian Isthmus and Their Nature
}

\author{
B. A. Assinovskaya ${ }^{a}$, I. P. Gabsatarova ${ }^{b}, *$, N. M. Panas ${ }^{a}$, and M. Uski ${ }^{c}$ \\ ${ }^{a}$ Federal Research Center, Geophysical Survey, Russian Academy of Sciences, St. Petersburg, 197140 Russia \\ ${ }^{b}$ Federal Research Center, Unified Geophysical Survey, Russian Academy of Sciences, Obninsk, 249035 Russia \\ ${ }^{c}$ Department of Geosciences and Geography, Institute of Seismology, University of Helsinki, Helsinki, 00014 Finland \\ *e-mail: ira@gsras.ru
}

\begin{abstract}
For the first time in aseismic Leningrad oblast, the local St. Petersburg seismic network recorded 32 compactly localized seismic events with a unique wave pattern and magnitudes $M_{L}=-0.6$ to +2.1 . The nature of the events has been studied, and spectrograms and cluster analysis are used to show the difference between the records of these events and blasts at the Vyborg station. The source parameters and focal mechanism of thrust-strike movement along a possible northwest-trending fault plane were determined, which proves the tectonic origin of the events. Synthetic seismograms of the strongest event on December 18, 2016, at 00:20 have been constructed, the shapes of which correspond to the position of the source at a depth of $2 \mathrm{~km}$. A map of earthquake epicenters has been compiled, and a 4-km-long NS-trending seismogenic zone has been identified as a fault that bounds the Vyborg rapakivi intrusion from the east, and possibly a new rupture that has occurred in near the long- and intensely functioning Erkilja quarry. The regional earthquakes that took place in the historical and instrumental periods of observations have been described. A database of blasts from known quarries has been created. The velocity model has been refined.
\end{abstract}

Keywords: industrial blast, quarry, tectonic earthquake, event catalog, seismic stations, Vyborg rapakivi intrusion

DOI: $10.3103 / \mathrm{S} 074792391901002 \mathrm{X}$

\section{INTRODUCTIONS}

In recent years, the St. Petersburg seismic network has recorded more than 30 weak seismic events of an unclear nature with epicenters around the Karelian Isthmus. These events were recorded in the period from March 2014 through December 2016.

Geographically, the Karelian Isthmus is a land area approximately $180 \times 100 \mathrm{~km}$ in size between the Gulf of Finland and Lake Ladoga; geologically, this is a transition zone from the Baltic Shield to the Russian Plate. The area, especially its northern half, is ubiquitously characterized by rock outcrops of granitic rocks of various origin. This has governed the dramatic development of the ore-mining industry here. Intensive blast-assisted quarrying (around 1500 blasts per year) of building materials has been underway since 1995 to the present. Suffice it to say that, today, this small area hosts the operations of more than 40 quarries. The quarry has been functioning for approximately 20 years. When it becomes flooded, blast operations move to a new spot.

This paper describes the results of a detailed study of events in 2014-2016 that locally occurred as swarms in the vicinity of the Erkilja quarry. Some of them took place at night, were felt macroseismically, and had records that appeared to differ from blasts, which made it possible to express a hypothesis about the tectonic origin of the events. It is well known that studying the seismicity of weakly active platform territories in a technogenically loaded setting requires long-term research to explain the nature of the recorded events.

\section{ST. PETERSBURG SEISMIC NETWORK}

The Pulkovo seismic station has operated in the area for more than 100 years, and its recording capabilities-evidenced by a comparative plot of noise spectra at night, the most quiescent time (Fig. 1) have made it possible to record remote and strong earthquakes. A regional network was installed in the 2000s to detect possible weak local earthquakes, the majority of which are recorded in the Russia-Finland border zone. Figure 2 shows the geographical location of the seismic stations. They were set up near Vyborg (VYB), on Valaam Island (VAL), and at the center of the Karelian Isthmus (IZM). In 2014, the network was augmented with the LOPUX station, installed in southwestern Leningrad oblast in the village of Lopukhinka.

The stations are equipped with KS36000, GS-13, or SM-3KV short-period seismometers, as well as dig- 


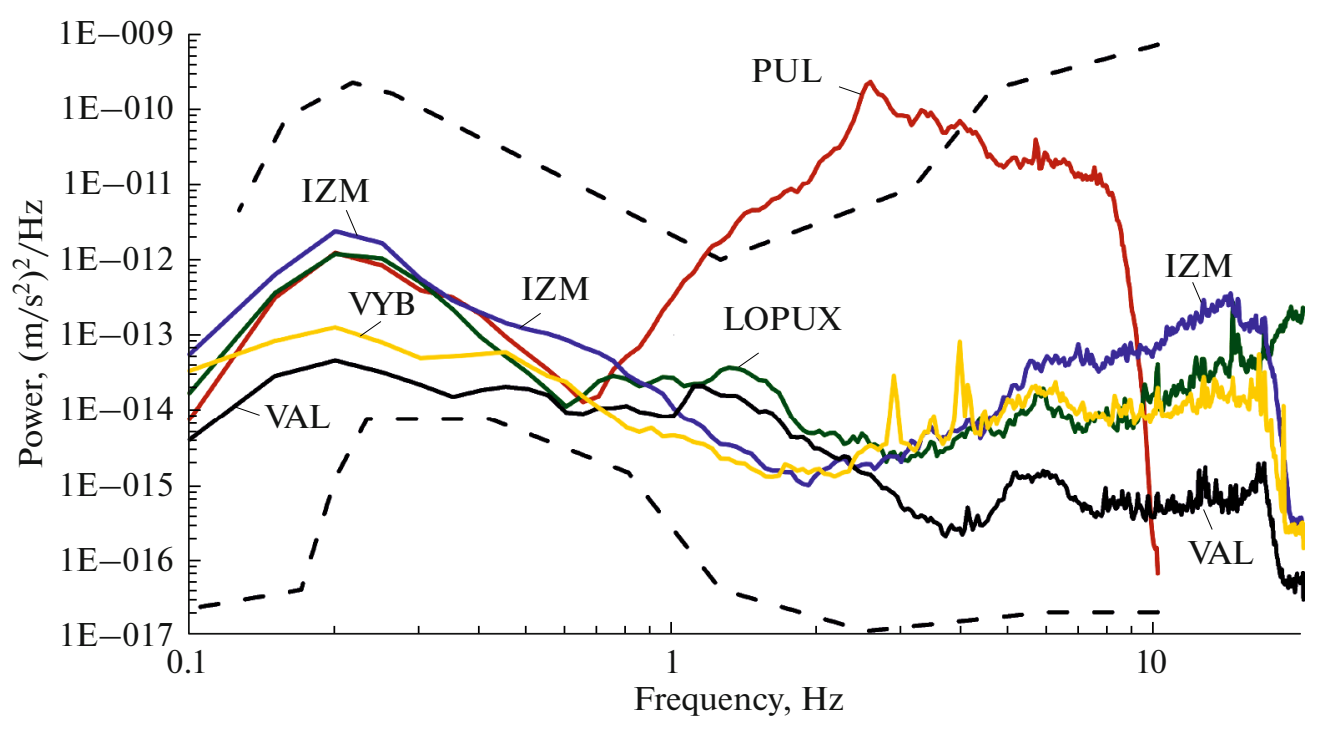

Fig. 1. Power spectra of nighttime noise in vertical component of seismic stations of St. Petersburg network compared to global nighttime low-noise (NLNM) and high-noise (NLHM) models (black dotted curves) (IASPEI..., 2002). Compiled by V. Karpinskii.

ital 16-bit SDAS or 24-bit UGRA recorders (the sampling rate is $40-50$ samples/s; the sensitivity is 2.00E-09-9.68E-10 (m/s)/samples). At each spot, the equipment has been installed on bedrock, except for stations VAL and VYB, which stand on rocky soil; the noise level is pervasively low (Fig. 1), which yields high-quality data, especially at the VAL station (Karpinskii et al., 2017).

In this study, to determine the focal mechanism and model the focal depth, we also include the seismic stations of Helsinki University's Institute of Seismology (Finland) and the Estonian Geological Survey: WJF, RUF, PVF, KAF, MEF, RAF, VSU, and ARVE, which are equipped with broadband and short-period devices, as well as two temporary stations KU12 and KU02.

\section{SEISMICITY}

The territory of the Karelian Isthmus is associated with weakly seismoactive areas. Historically, only three seismic activity zones are known: the Ladoga, Gromovo, and Vyborg, where more than a century ago, earthquakes with magnitudes $M \leq 3$ occurred (www.seismo.helsinki.fi; Renquist, 1930; Assinovskaya and Nikonov, 2003) (see Fig. 2).

The map contains the following notation: black circles, historical earthquakes; white squares, events of the instrumental observation period; the sizes of symbols are proportional to $M / 10$ and $M / 5$, respectively. Rhombs mark the seismic stations. The occurrence dates are included for historical events of the Karelian Isthmus.

The focus of the historical earthquake at Sakkola (settlement of Gromovo) on Lake Sukhodolskoye, which occurred on May 13, 1902, was supposedly at a depth of around $3 \mathrm{~km}$ and the shaking intensity was estimated at 3-4 on the MSK-64 scale. In 2009, geological study was carried out in the epicentral zone of this event (Assinovskaya et al., 2010); as a result, a neotectonic structure was discovered on the northern shore of Lake Sukhodolskoye. The revealed deformations were Holocene in age; judging from the materials of remote research, they mark a tectonic knot-an intersection of probable tectonic faulting in different directions.

The earthquake of February 2, 1870, with an intensity of 4 occurred in Vyborg Bay. It had a focal depth of around $3 \mathrm{~km}$ and a magnitude of $M \approx 2.0$. This event, just like the previous one, is described in the catalog (Renquist, 1930): "The earthquake occurred on February 1 around 10:00 p.m. ... at the entrance to Vyborg Harbor. The shaking was so strong that a man quickly dashed into the yard, felt that the earth was moving, and heard a loud crash... . Another eyewitness account states: There was a strong boom resembling a cannon shot... followed by mild sea waves (seaquake), and large cracks appeared in the ice (ice fracturing)."

Three earthquakes occurred on the eastern shore of Lake Ladoga in the settlement of Kaukolo (Sevastyanovo) in 1926: on a night in February (no date); on March 3 at 22:00; and on March 8 at 24:00, sounds similar to a gun or cannon firing outside were noted; as well, walls shook, lamps swayed, beds trembled, and people were awakened. Fissures were observed in a field in February. These data correspond to an intensity of 4, a focal depth of $3 \mathrm{~km}$, and a magnitude of $M \approx 2.0$ (Assinovskaya et al, 2010). There is the opinion that most of the events described above were related to ice fracturing (Assinovskaya and Nikonov, 


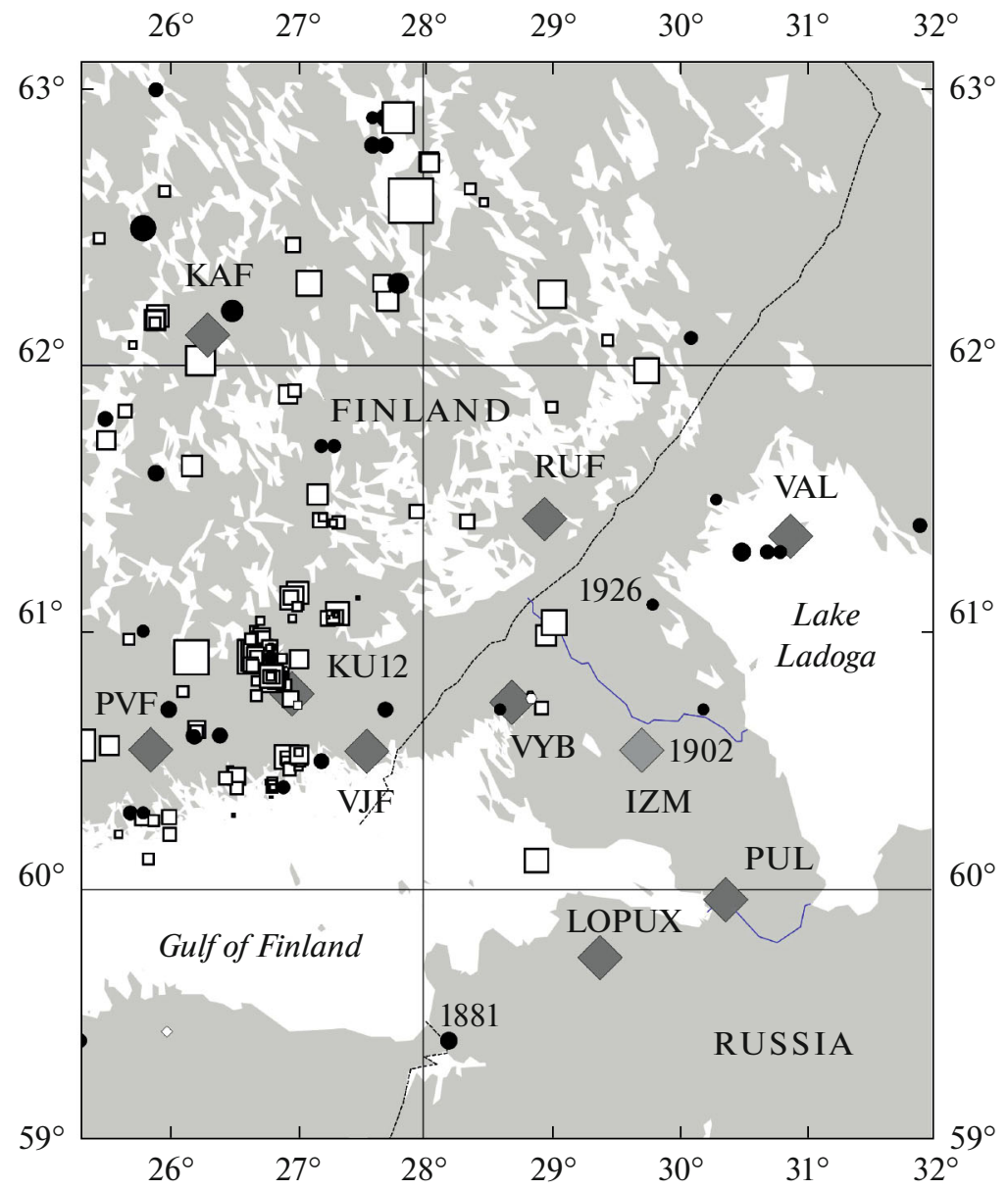

Fig. 2. Seismic network and seismicity of Karelian Isthmus and adjacent areas.

2003). However, these conclusions should be approached with caution; e.g., near Riga, where such events took place, a tectonic earthquake also occurred in the recent past (V. Nikulin, oral communication).

The Narva earthquake occurred on the coast of the Gulf of Finland on January 28, 1881; its intensity on the MSK-64 scale was determined as 6 (Nikonov, 2011); taking into account the focal depth of $3 \mathrm{~km}$, it had a magnitude of $M \approx 3.5$. The epicentral zone of this event was located west of Narva. The event is associated with the well-known seismotectonic knot in the Narva active zone (Nikonov, 2011).

The earthquake of July 11, 2007, at the center of the eastern Gulf of Finland $\left(M_{L}=2.0, h=2.9 \mathrm{~km}\right)$ is evidence of the activity of the southern zone of the rapakivi massif (Assinovskaya and Verzilin, 2007). The focal mechanism was a normal fault with a sublatitudinally dipping fault plane with a larger shear component.

In addition, rock paleodeformations were found in the so-called Inostrantsev Caves in the vicinity of Kammenogorsk on the Karelian Isthmus (Nikonov et al., 2014). It was established that no fewer than three seismic events with intensities of 7-9 occurred during the last glacial period, deglaciation, and postglacial period.

Recent seismicity is represented by a number of weak earthquakes, the most interesting of which are two earthquake swarm zones recorded instrumentally near the northern shore of the Gulf of Finland. The first swarm was recorded in Anjalankoski in 2003, and the second, in Kouvola in December 2011 (Uski et al, 2006; Smedberg et al., 2012). In the first case, from May through October 2003, $18\left(M_{L}=0.6-2.1\right)$ earthquakes with identically shaped records occurred. The events were associated with northeast-trending zones around $1 \mathrm{~km}$ in extent. $R g$ and $s P$ wave modeling allowed to authors to calculate the focal depth as no greater than $2 \mathrm{~km}$. The focal mechanism was determined as normal-strike-slip movement along a vertical fault plane with a dip of $250^{\circ}$. This faulting is hosted within the Finnish part of the Vyborg rapakivi granite batholith.

The second swarm, recorded near the city of Kouvola, consisted of more than 150 earthquakes with $M=0.4-2.8$ and focal parameters similar to the 2003 
Table 1. Quarries on Karelian Isthmus

\begin{tabular}{l|c}
\hline \multicolumn{1}{c|}{ Quarry } & Number of blasts studied \\
\hline Erkilja & 21 \\
Krasnovskoe & 5 \\
KKU & 24 \\
Ostrovskoye & 24 \\
Vuoksi & 4 \\
Vozrozhdenie & 10 \\
Total & 88 \\
\hline
\end{tabular}

Table 2. Regional velocity model of study area

\begin{tabular}{c|c|c}
\hline$H, \mathrm{~km}$ & $V_{p}, \mathrm{~km} / \mathrm{s}$ & $V_{s}, \mathrm{~km} / \mathrm{s}$ \\
\hline 0.0 & 6.08 & 3.44 \\
25.0 & 6.7 & 3.84 \\
41.0 & 8.1 & 4.65 \\
80.0 & 8.5 & 4.88 \\
\hline
\end{tabular}

swarm and the same association with the rapakivi granite intrusion. In addition, a study of detailed tectonic maps made it possible to establish in the mentioned areas not only the above-mentioned faulting, but also faulting orthogonal to the former, which allows the conclusion that the described sets of earthquakes are probably localized in variously trending fault zones of relatively small extent.

\section{SEISMIC ACTIVITY IN 2014-2016}

Throughout 2014-2016, the St. Petersburg seismic network recorded 32 unusual events assumed to be earthquakes. This is a unique situation for the weakly active region. The events were localized at the center of the isthmus near the active Erkilja quarry; therefore, it was necessary to prove that they were not industrial blasts.

Seismic recording in this area has its own peculiarities as a result of the large number of blasting areas, along with their continual movement, the absence of objective information on the blast parameters in particular areas, etc. In addition to the St. Petersburg network, blasts on the Karelian Isthmus are recorded by Helsinki University's Institute of Seismology (Finland). The vast Finnish network is unidirectional with respect to the Karelian Isthmus and covers blocks of Earth's crust with different depth structures. Therefore, the Finnish network localizes events on Russian territory with a large error.

Taking into account that tectonoseismic events need to be localized as accurately as possible, whenever we could, we gathered reliable information from primary sources on the place and time of blast operations at certain quarries in the central part of the Kare- lian Isthmus. Owing to the obtained data, we carefully analyzed the technical information and waveforms of blasting on the Karelian Isthmus recorded by the St. Petersburg seismic network, which consists of four closely spaced stations. As a result, we obtained localization data on 88 blasts in the period from January through October 2016 and studied their waveforms (Table 1).

Due to the closeness of the quarries, the blasts have similar waveforms at the stations. Certain features have been noted in the seismograms of blasts from recently opened quarries, e.g., the Vuoksi quarry (they were of higher quality), as well as the records of events from sources close to the stations. For example, the Erkilja and Vozrozhdenie quarries are located $5 \mathrm{~km}$ from the VYB station.

Comparison of the blast localization results from the St. Petersburg network data with collected objective data showed that the network determines event coordinates with an uncertainty of no more than $0.5 \mathrm{~km}$.

It was also revealed that when 5-15 Finnish stations at remote distances of $80-500 \mathrm{~km}$ were included in the processing, it resulted in a northwest deviation of $2-9 \mathrm{~km}$ from the true epicenter.

Automatic location by Helsinki University's Institute of Seismology also has substantial errors in determining the coordinates of events occurring on the Karelian Isthmus. Based on these data, the epicenters of blasts are mainly shifted southeast by $1-12 \mathrm{~km}$ (Fig. 3).

The collected data for precisely localized events were used to refine the regional crustal velocity model. Using the Wadati method, the true time at the focus and the travel time of the main waves were determined. As a result, we obtained values for the velocities and thickness of the Earth's crust. The velocity values in the upper crust in the area of the Karelian Isthmus were obtained in 2009, when a network of six specially installed stations recorded a strong blast from the Gavrilovo quarry. The regional velocity model is presented in Table 2.

Before discussing localization of events and catalog analysis, let us describe their typical wave pattern. Figure 4 shows the seismograms of the strongest event from the recorded sequence; the records are equalized with respect to the first arrival $P g$ and filtered in the 1$5 \mathrm{~Hz}$ frequency range. The distances from the epicenter were as follows, km: VYB, 8; IZM, 53; LOPUX, 122; VAL, 129.

The main features of the records are, first, the presence in the $S$-wave composition of a characteristic high-amplitude and high-frequency group of vibrations with a duration of $5 \mathrm{~s}$; second, the presence of $s P$ waves at the VYB station, and frequently at the other stations $0.3-0.7 \mathrm{~s}$ after the first arrival; third, a Rayleigh wave of comparatively small amplitude. All 32 recorded events had, independent of magnitude, 


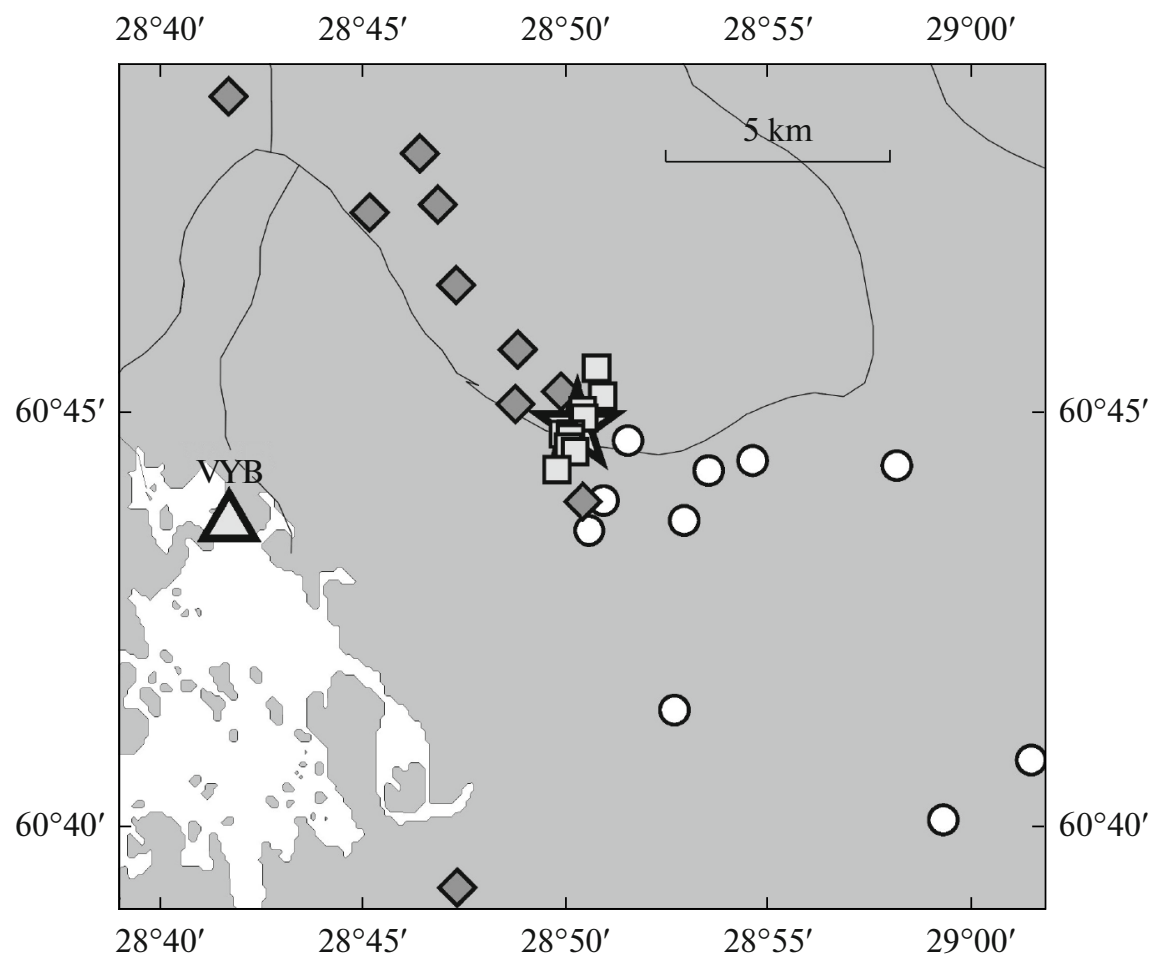

Fig. 3. Map of blast epicenters of Erkilja quarry. Diamonds show events jointly processed by St. Petersburg and Finnish seismic network; circles, data of Finland stations; squares, data of St. Petersburg stations (VAL, VYB, IZM, LOPUX); star, quarry; triangle, VYB station.

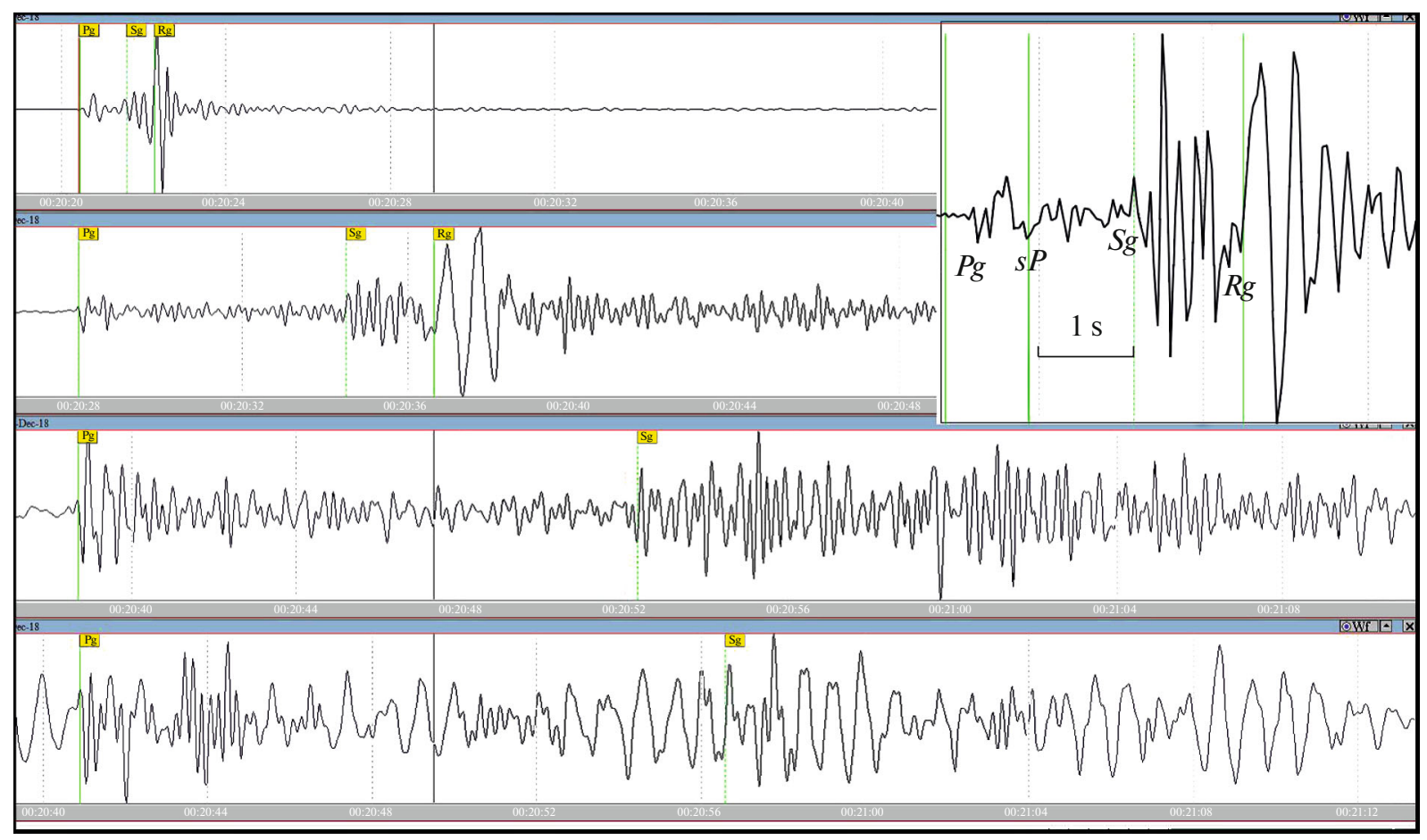

Fig. 4. Records of vertical component of VYB, IZM, LOPUX, and VAL stations (from top to bottom, respectively) of event on December 18, 2016, at 00:20 with $M_{L}=2.1$, filtered in the 1-5 Hz band (third-order Butterworth filter). Inset: Unfiltered record of vertical component of VYB station; arrival of $s P$ phase shown. 
wave patterns similar to that mentioned above, which indicates their generation by a single source.

Let us present analytical proof that the seismic records of events, presumed earthquakes, differ substantially from blast records.

\section{STUDY OF THE WAVEFORM AND FREQUENCY-COMPOSITION FEATURES OF SEISMIC EVENTS AND CLASSIFICATION BY CLUSTER ANALYSIS}

\section{Study Methods}

In many areas of the East European Platform, where the networks of the Federal Research Center, Geophysical Survey, Russian Academy of Sciences ( GS RAS) carries out observations (Voronezh crystalline massif, Arkhangelsk oblast, the eastern part of the Baltic Shield on the Kola Peninsula, etc.), a number of data processing methods are applied to recognize the nature of events (Vzryvy..., 2013).

The most informative among them are the specific features of the wave pattern of natural and technogenic events in the spatial and temporal domains, spectrograms, and cluster analysis for classifying the shapes of envelopes. These methods were applied in the present study.

The wave pattern and frequency composition of events were studied in order to find the distinguishing properties of blast and earthquake records at the same station. The VYB station, at a distance of approximately $5 \mathrm{~km}$ from the epicenters, was chosen for this purpose. Preliminary analysis of the records showed that the first arrival of the $P g$ wave in the vertical channel shz is weakly detected and is clearer in the horizontal channel she.

A three-component record was subjected to polarization transformation (rotation of the record taking into account the azimuth from the epicenter to the station $\left(\mathrm{Az}=246^{\circ}\right)$ and the angle of a ray departure from a near-surface ( $h=2.0 \mathrm{~km}$ (Panas and Assinovskaya, 2017)) and nearby event $\left(\delta=20^{\circ}\right)$; the record is decomposed into the purely vertical, transverse, and radial components (Geotool software was used (Coyne et al., 2003). The character of the record changed, becoming a more adequate depiction of seismic phase polarization: The $P g$ wave was more pronounced on the vertical component; the $S g$ wave, on the transverse component; and the $R g$ wave, on the radial component. As an example, Fig. 5 presents records of three-component channels (shz, shn, she) in accordance with the arrangement of the seismometers and records of transformed velocigrams (shv, sht, shr) for two events: one on March 6, 2014 at 18:42, and and the other on December 18, 2016 at 00:54.

The transformed records of all events (blasts and earthquakes) were subsequently used to construct spectrograms, as well as to classify events according to envelope shape using cluster analysis.

The algorithm for constructing the spectrograms was as follows: a moving time window $(0.5 \mathrm{~s}$ with $50 \%$ overlap) was applied to the record of the event (a $9 \mathrm{~s}$ fragment was taken); the power spectrum was calculated for each position of the window. For clarity, the spectral amplitude in the spectrograms is normalized to the maximum and displayed in the color range of a two-dimensional image (2D spectrogram), as shown in Figs. 6 and 7.

In a number of studies on recognizing the nature of events from digital records (see, e.g., Chernobay and Gabsatarova, 1999), it was established that classification of events according to the shape of the envelopes of records can be highly effective for grouping events, including blasts and earthquakes, especially if the records are prefiltered and represented in the most informative frequency bands. For our purposes, the envelopes of the transformed records of VYB station, which were filtered in the frequency band of $2-8 \mathrm{~Hz}$, were constructed by Hilbert transform in the SAC2000 program (Golstein et al., 2003); the Geotool program (Coyne et al. 2003) was used to establish similarity between envelopes, which made it possible to calculate the cross correlation coefficients of the time series. It is assumed that the maximum value (close to 1.0) of the cross correlation function entails the high probability that events have similar sources and seismic wave propagation paths.

General ideas on classifying events using cluster analysis discussed in (Aivazyan et al., 1989) informed our choice of the method for classifying seismic events. A distance matrix $\left\{\rho_{i j}=D(X i, X j)\right\}$ was sent to the input of the analytical unit. In the study, a distance $D$ was applied (Chernobye et al., 1995), which for the pair of records $s_{1}$ and $s_{2}$ was determined as

$$
D\left(\mathrm{~s}_{1} \mathrm{~s}_{2}\right)=\left(1-r_{12}^{2}\right) / r_{12}^{2},
$$

where $r_{12}$ is the maximum value of the cross correlation function for the two envelopes.

Formula (1) was realized in the hierarchical cluster analysis program with the construction of the "tree" (dendogram) NEIGHBOR in accordance with the distance of objects (Chernobye et al., 1995).

To construct the hierarchical dendogram, three methods of establishing the relationship between objects in the sampling were carried out:

(1) nearest neighbor method (single linkage);

(2) furthest neighbor method (complete linkage)

(3) pair-group average method (the distance between two clusters is calculated as the average distance between all pairs of objects in the two different clusters). 
(a)

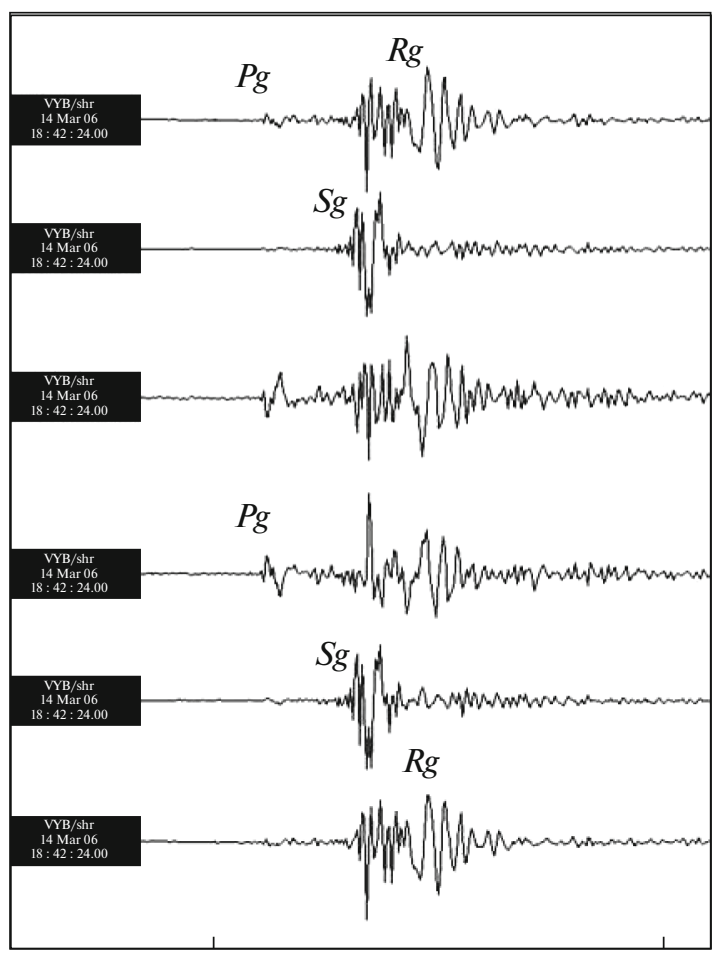

00:00:10

Time (hh:mm:ss) (b)

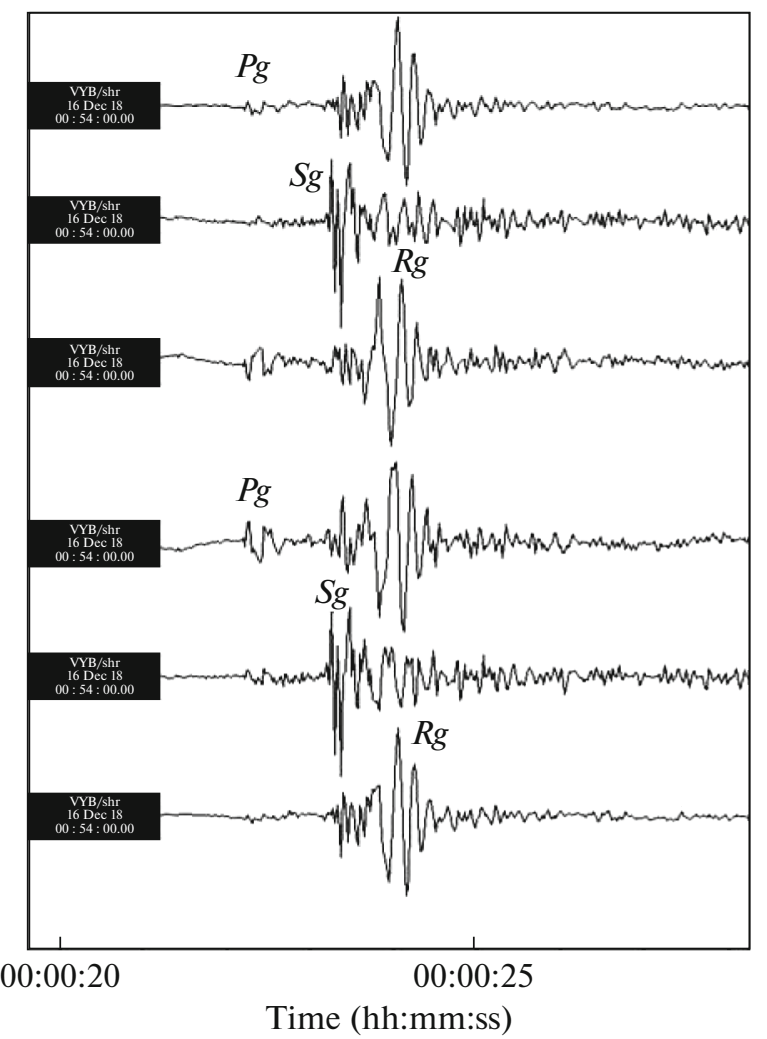

Fig. 5. Three-component record of velocigrams of shz, shn, and she channels, obtained as a result of rotation and decomposition into vertical (shv), transverse (sht), and radial (shr) components of events of (a) March 6, 2014, and (b) December $18,2016$.

\section{RESULTS}

The wave pattern of events is illustrated well by the spectrograms of a $9 \mathrm{~s}$ fragment from a VYB station record for the earthquake of December 18, 2016, at $00: 30$ with $M_{L}=1.4$ and a similar fragment of a blast record of February 3, 2016 at 12:42. The spectrograms were constructed for records of the shz, shn, and she components (see Figs. 6a-6c); one can see that the first $P g$ wave is weakly pronounced in the shz channel (see Fig. 6a), while in the she channel, its energy is even more pronounced (see Fig. 6c).

From the spectrograms of transformed earthquake records (see Figs. 6d-6f), the wave pattern consists of the longitudinal $P g$ wave manifested in the vertical component in a wide frequency range $(2-16 \mathrm{~Hz})$; in the same frequency range, the $S g$ wave is manifested in the transverse component; the energy of the $S g$ wave exceeds that of the $P g$ wave by $20 \%$. The surface $R g$ wave is starkly pronounced in the vertical and radial components and is comparable in energy to the $\mathrm{Sg}$ wave.

In the spectrograms of the blast on June 3, 2016, at 12:40 (see Figs. 7a-7f), constructed in the same way as for the earthquake, the group of $S g+R g$ waves is more compactly localized in terms of frequency in all components. The pretransformation $P g$ wave has an energy maximum in the she component, and post transformation, in the vertical component. The level of the energy maximum detected in this wave is comparable to the $R g$ wave.

Thus, the spectrograms of the blast and earthquake records underscore the explicit differences in the blast and earthquake wave patterns.

Analysis of the records by finding the cross correlation functions of the envelopes and cluster analysis by the complete linkage method and pair-group average method made it possible to quantitatively estimate the dissimilarity of the blast and earthquake records recorded in the near field and the similarity of earthquakes with each other. For this problem, the envelopes of the radial component from the prefiltered record in the $2-8 \mathrm{~Hz}$ band were the most informative (Fig. 8).

The calculated cross correlation coefficient matrix of a $4 \mathrm{~s}$ fragment of envelopes showed that for an earthquake event, a close relationship is established with $K=0.95-0.99$, while for blast events, the relationship is not as close $(K=0.79-0.88)$, which confirms a nearby source for natural events and a lesser similarity of blast records related to the different event triggers. The correlation between blast envelopes and earthquake envelopes is even smaller: $K=0.66-0.85$. This 
(a)

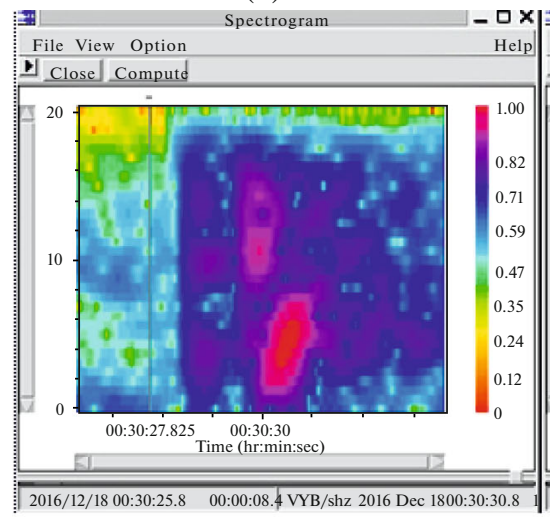

(d) (b)

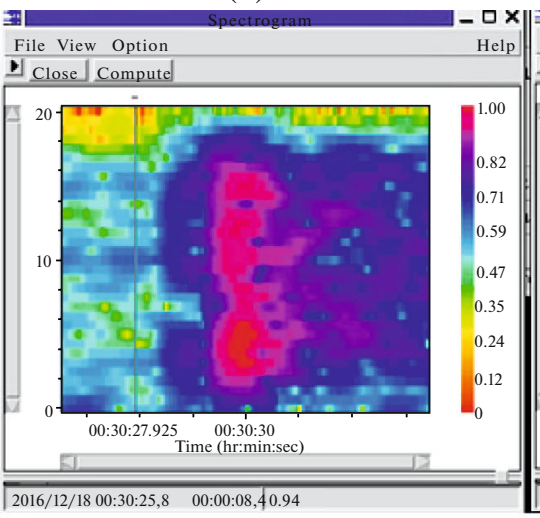

(e)

(c)

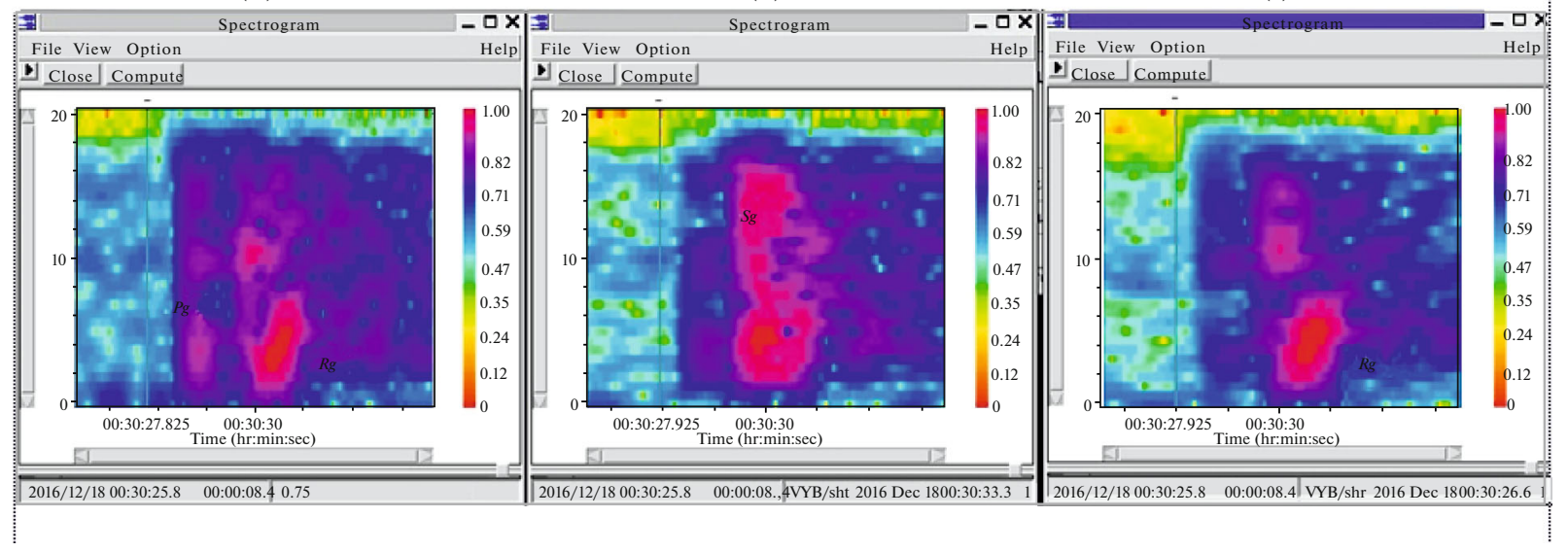

Fig. 6. Spectrograms of $9 \mathrm{~s}$ fragment of record at VYB station for earthquake of December 18, 2016 at $00: 30$ with $M_{L}=1.4$ : (a) original vertical component shz; $(b, c)$ horizontal components shn and she, respectively: $(\mathrm{d}-\mathrm{f})$ records after rotation: vertical (shv), transverse (sht), and radial (shr) components.

is undoubtedly reflected in the obtained distance values $D\left(\mathrm{~s}_{1} \mathrm{~s}_{2}\right)$ used to construct the dendograms: for earthquakes $D\left(\mathrm{~s}_{1} \mathrm{~s}_{2}\right)=0.02-0.2$, while for blasts $D\left(\mathrm{~s}_{1} \mathrm{~s}_{2}\right)=0.30-0.60$, which was reflected in the dendogram, showing the presence of two classes: with a dense branch structure for earthquakes and longer branches for blasts.

This is particularly clear in the dendogram constructed by the complete link (farthest neighbor) method (Fig. 9a). In the dendrogram constructed by the pair group method with arithmetic mean (Fig. 9b), a similar pattern was obtained, but two "blasts" (2 and 4) ended up in an independent class. It should be noted that no blast fell into the earthquake class. The distance between classes (groups of branches) was $D\left(\mathrm{~s}_{1} \mathrm{~s}_{2}\right)=1.34$ in the complete linkage method and $D\left(\mathrm{~s}_{1} \mathrm{~s}_{2}\right)=0.767$ in the pair-group average method (Fig. 9), which indicates a large difference between these groups as independent clusters of events. The division into two classes can be considered reliable.

However, one event from the earthquake category (December 15-18, 2016, at 02:50) ended up a neighbor of blast class events (Fig. 9a). In this case, when similarity cannot be attained in the time domain, the event spectra are additionally studied. This was done for several events, including earthquake 15 .

Figure 10 shows the records of three earthquakes and three blasts in the vertical component and identically smoothed displacement amplitude spectra $(3.7 \mathrm{~s}$ fragment, including the entire wave pattern) for these events. One can distinctly see that the earthquake spectra, among which the upper seismogram pertains to earthquake 15, whose classification by envelope shape is unmistakable, have common minima ( 8.3 and $12.1 \mathrm{~Hz}$ ) and maxima (3-5.5, 10-11.5, and $14.5 \mathrm{~Hz}$ ).

The blast spectra have no such reliable similarity among themselves, but they all are identically divided into two zones: low-frequency up to $f<8 \mathrm{~Hz}$ with maximum energy, and high-frequency with $f>8 \mathrm{~Hz}$, which is flattened and less energetically pronounced; they differ significantly from the earthquake spectra and, therefore, from event 15 . The form of the spectra correlates quite well with the earlier described spectrograms typical of blasts and earthquakes.

Thus, our analysis of records and spectra makes it possible to confirm the proffered hypothesis on the 
(a)

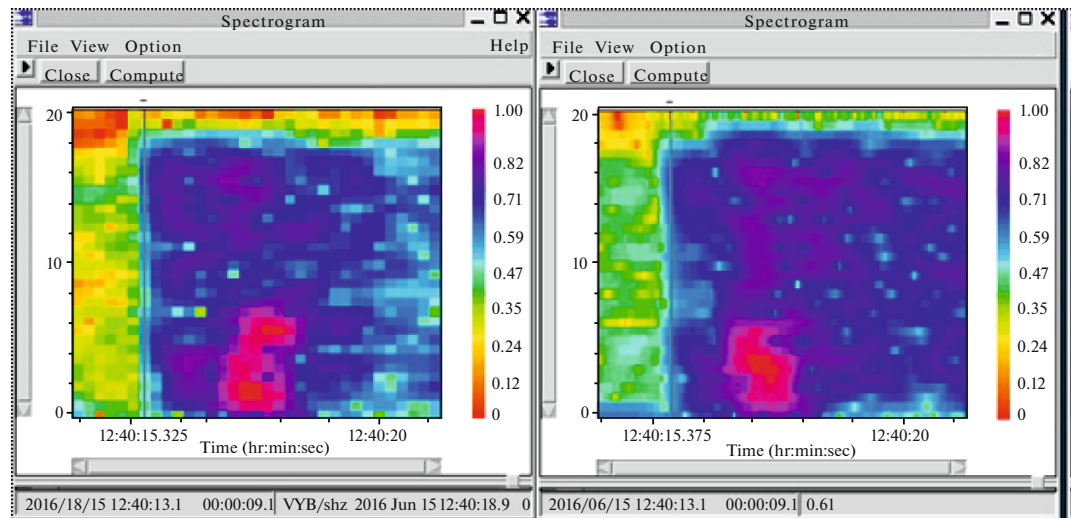

(d)

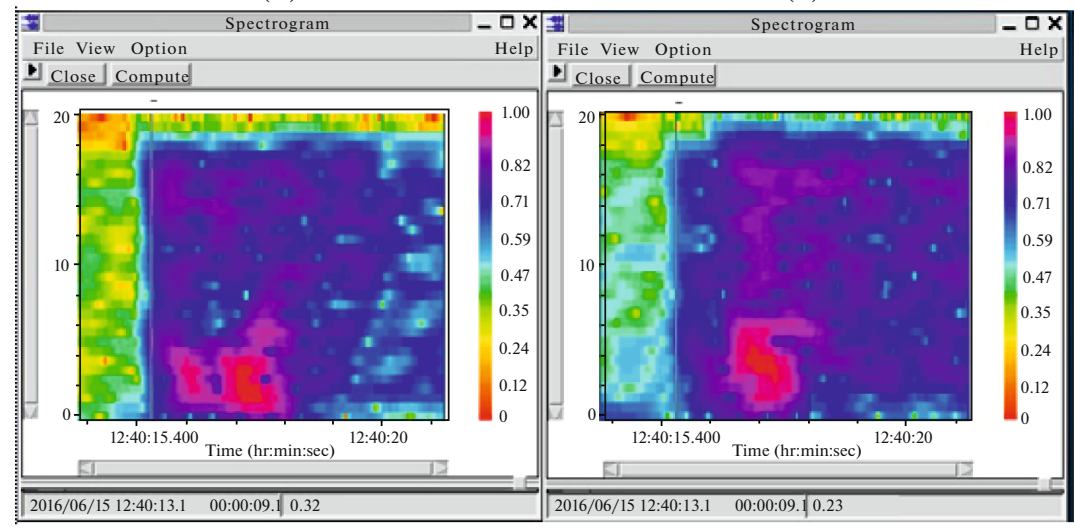

(c)

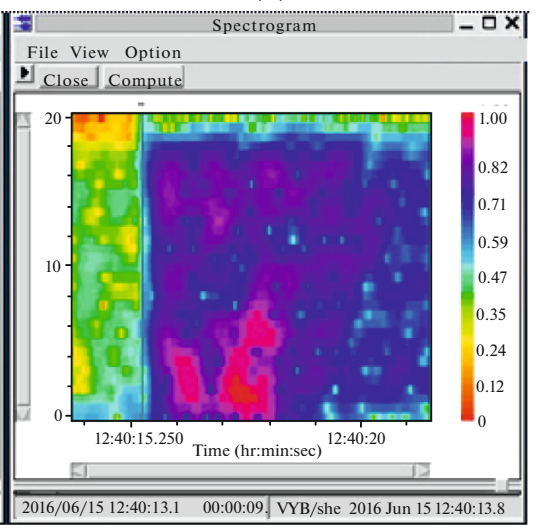

(f)

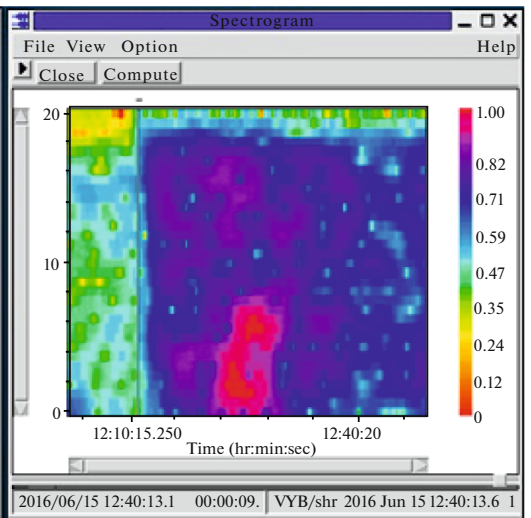

Fig. 7. Spectrograms of $9 \mathrm{~s}$ fragment of record at VYB station for blast of June 5, 2016, at 12:40: (a) original vertical component shz; (b, c) horizontal components shn and she, respectively: $(d-f)$ records after rotation: vertical, transverse, and radial components.

recording of earthquakes and substantial differences of their records and spectra from known blasts in nearby quarries.

\section{EARTHQUAKE CATALOG}

To determine the main parameters of earthquake hypocenters and their magnitudes, the WSG and SEISAN software systems (http://www.uib.no) were used; uncertainty estimates were obtained with the
HYPODD program (http://www.ldeo.columbia.edu). For the strongest earthquakes, these ended up being $0.5 \times 0.9 \mathrm{~km}$ in area and $0.5 \times 0.9 \mathrm{~km}$ in depth (Table 3).

For the strongest event of December 18, 2016 at 00:20, it was possible to construct the focal mechanism of the earthquake using the first $P$ wave arrivals of the four St. Petersburg stations, as well as of the Finnish and Estonian networks. The obtained solution is evidence of oblique slip along the fault plane

Table 3. Earthquake parameters and localization errors

\begin{tabular}{l|c|c|c|c|c|l|l|l}
\hline $\begin{array}{c}\text { Date, } \\
\text { day-month- } \\
\text { year }\end{array}$ & $\begin{array}{c}\text { Time } \\
\text { hh:mm:ss }\end{array}$ & Latitude, ${ }^{\circ} \mathrm{N}$ & Latitude, ${ }^{\circ} \mathrm{E}$ & $M_{L}$ & $h, \mathrm{~km}$ & $D x, \mathrm{~m}$ & $D y, \mathrm{~m}$ & $D z, \mathrm{~m}$ \\
\hline 06-Mar-14 & $18: 42: 32.33$ & 60.760 & 28.845 & 1.3 & 1.8 & 574.7 & 665.3 & 953.1 \\
11-Jul-16 & $01: 47: 45.96$ & 60.743 & 28.848 & 1.05 & 1.2 & 408.8 & 534.4 & 661.5 \\
18-Dec-16 & $00: 20: 19.39$ & 60.750 & 28.852 & 2.1 & 2 & 533.9 & 527.1 & 743.6 \\
18-Dec-16 & $00: 30: 27.59$ & 60.743 & 28.846 & 1.4 & 1.2 & 470.7 & 539 & 599 \\
18-Dec-16 & $00: 54: 21.12$ & 60.737 & 28.852 & 0.8 & 1.2 & 454 & 910.9 & 772.1 \\
18-Dec-16 & $02: 50: 26.08$ & 60.730 & 28.840 & 1.3 & 1.2 & 411.7 & 390.9 & 533.8 \\
\hline
\end{tabular}


(a)

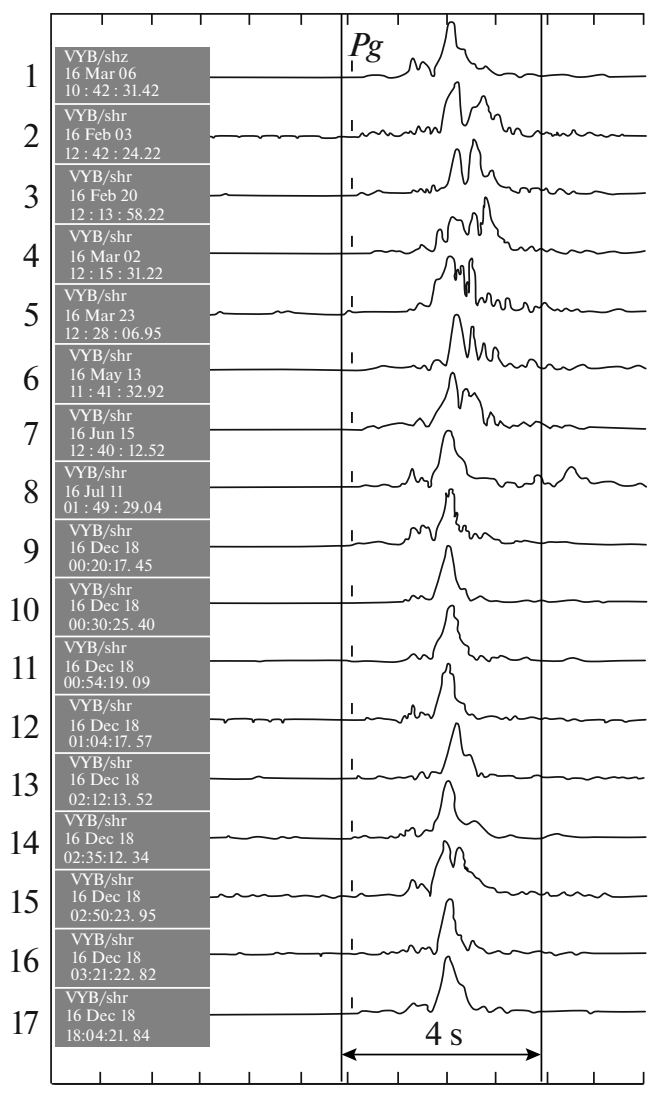

(b)

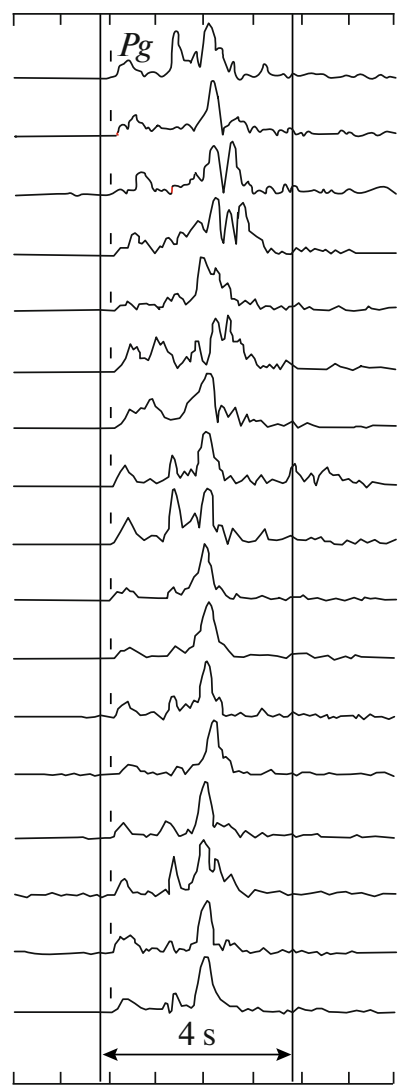

Time, $\mathrm{s}$ (c)

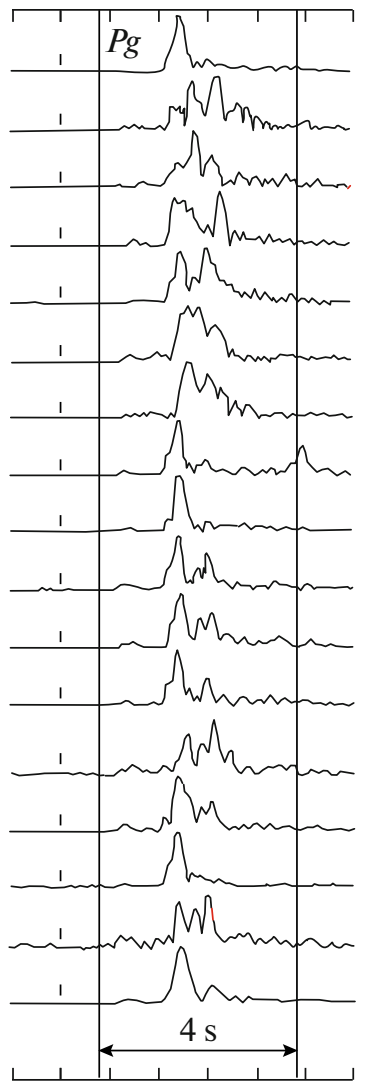

Fig. 8. Envelopes of records of (a) radial, (b) vertical, and (c) transverse components at VYB station, filtered in $2-8 \mathrm{~Hz}$ band. Seventeen studied seismic events are arranged in chronological order and equalized with respect to first arrival of $P g$ wave. Lines 1 and $8-17$, correspond to earthquakes; $2-7$, known quarry blasts.

with a dip of $75^{\circ}$ and a NW-trending rupture plane of $308^{\circ}$. According to the similarity of the waveforms and polarity of the first arrivals, the mechanisms for all the earthquakes of the recorded swarm are similar and the geodynamics of the zone is determined by NWtrending compressional stress and submeridional subvertical extension (Fig. 11).

The focal depths were determined by three methods: (1) during localization by the above-mentioned programs based on a regional model (see Table 2); (2) by identifying the deep $S p$ phase in the seismograms (Fig. 4) and interpreting the $s P-P$ travel-time curve (Kennett, 1991); (3) by constructing synthetic seismograms (described in greater detail below).

\section{MODELING SOURCE DEPTH WITH SYNTHETIC SEISMOGRAMS}

The shallow source depths obtained for the events in Vyborg (see Table 3) are consistent with earlier observations based on depth estimates for earthquakes that occurred within the Vyborg rapakivi granite batholith. A characteristic feature of these events is the presence of a strong $R g$ wave in the seismograms of stations close to the source. Since the short-period $R g$ phases propagate only in the uppermost crust, they impose strict limitations on estimating the source depth. The differences in the arrival times of the $s P-P$ phases are also useful for estimating the source depth, because they are relatively insensitive to the details of the crustal velocity model. In (Uski et al., 2006; Smedberg et al., 2012), synthetic modeling of $R g$ vibrations and other depth-sensitive phases were used to determine the depths of earthquakes within the Finnish part of the Vyborg rapakivi intrusion.

In this case, modeling was done for the main event recorded in its entirety. The synthetic oscillograms were calculated by the reflectivity method (Kind, 1978, 1979) using the source parameters and local velocity model parameters (Table 4 ). The velocity model was modified for eastern part of the Vyborg rapakivi granite intrusion after (Uski et al., 2006). It should be noted that it also differs from the one (see Table 2) used in this work to localize events, since in this case, stations installed in lower-velocity settings were also used. 
(a)

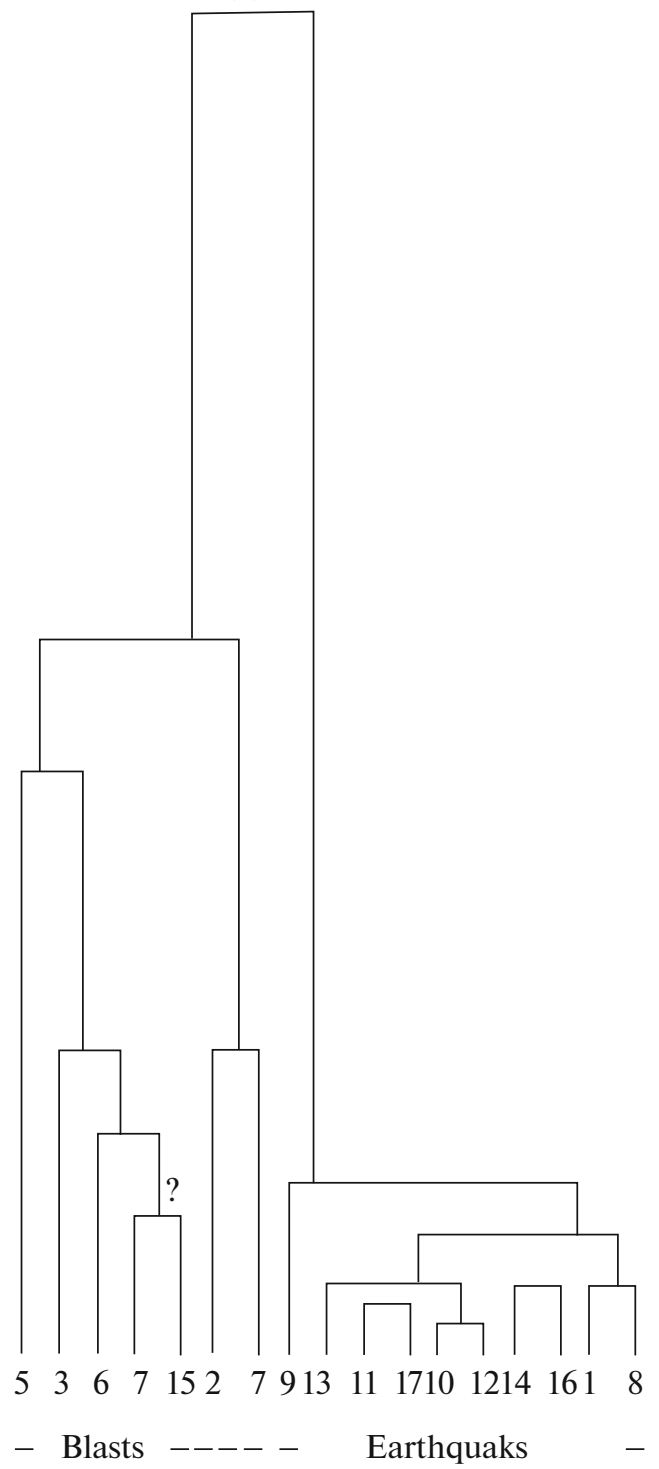

(b)

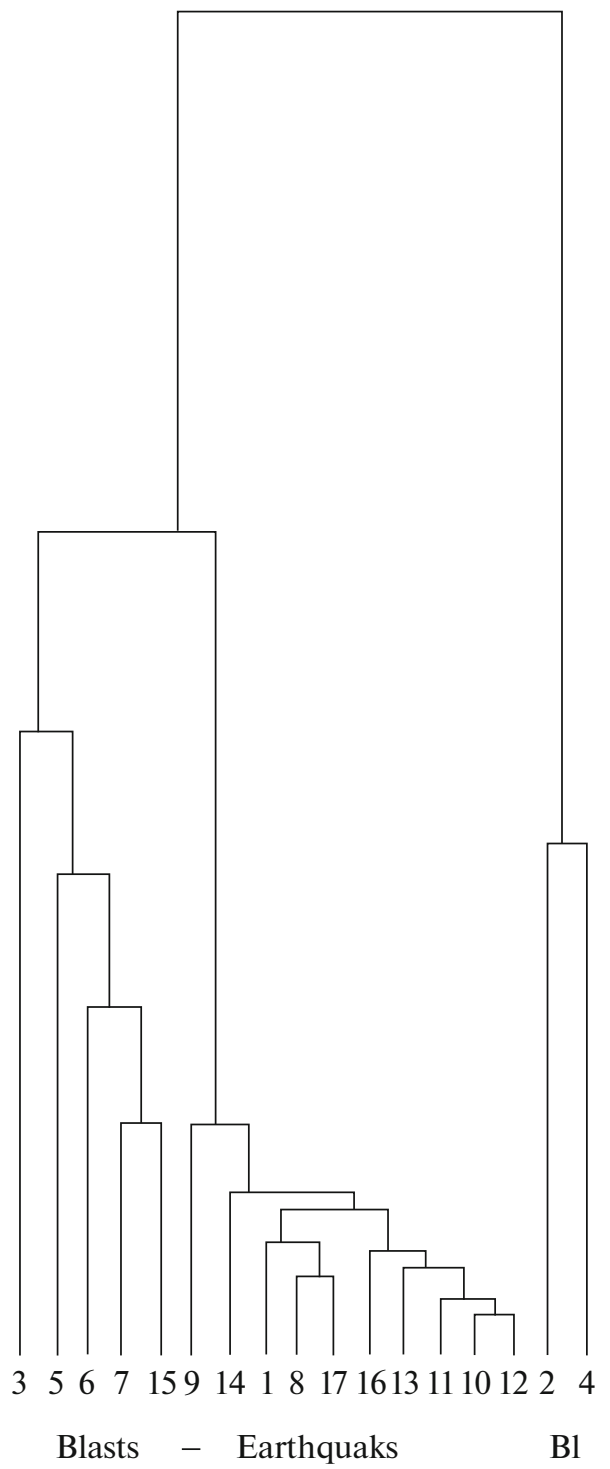

Fig. 9. Dendograms of hierarchical cluster analysis constructed by total link method (furthest neighbor) (a) and pair-group average method (b) for envelopes of records of 17 events (VYB station, radial component).

The maximum ratios of the $R g$ amplitude to the amplitude of body waves and the difference $S p-P$ were measured in seven seismograms recorded at distances of 9-130 km.

Figure 12 shows examples of synthetic oscillogram modeling. The seimograms of the main event at the ISZ and KY02 stations are compared with synthetic signals calculated for depths of 1 and $5 \mathrm{~km}$. Clearly, $R g$ is the dominant phase with a source depth of up to $3 \mathrm{~km}$, but its amplitude rapidly decays in the coda with increasing depth. The IZM station is close to the nodal line of the $P$ and $S V$ focal mechanism; therefore, the $P$, $S$, and $s P$ phases are weak compared to $R g$. However, both the ratio of the $s P$ and $R g$ amplitude to the $P$ wave amplitude in the initial seismogram correspond best to the synthetic signals at a depth of $1.5-2.5 \mathrm{~km}$.
The KY02 seismogram in Fig. 12b was recorded at a distance of $115 \mathrm{~km}$. Since the $R g$ phase decays more rapidly than the $P$ wave, its relative amplitude at this

Table 4. Parameters used for constructing synthetic seismograms. Modified for eastern part of Vyborg rapakivi intrusion after (Uski et al., 2006)

\begin{tabular}{c|c|c|c|r|r}
\hline $\begin{array}{c}\text { Layer thickness, } \\
\mathrm{km}\end{array}$ & $\begin{array}{c}V_{p}, \\
\mathrm{~km} / \mathrm{s}\end{array}$ & $\begin{array}{c}V_{s}, \\
\mathrm{~km} / \mathrm{s}\end{array}$ & $V_{p} / V_{a}$ & $Q_{P}$ & $Q_{S}$ \\
\hline $0.0-0.8$ & 5.90 & 3.13 & 1.89 & 60 & 40 \\
$0.8-15.0$ & 6.17 & 3.54 & 1.74 & 800 & 600 \\
$15.0-42.0$ & 6.62 & 3.80 & 1.74 & 800 & 600 \\
$42.0-\infty$ & 8.10 & 4.64 & 1.75 & 2000 & 2000 \\
\hline
\end{tabular}




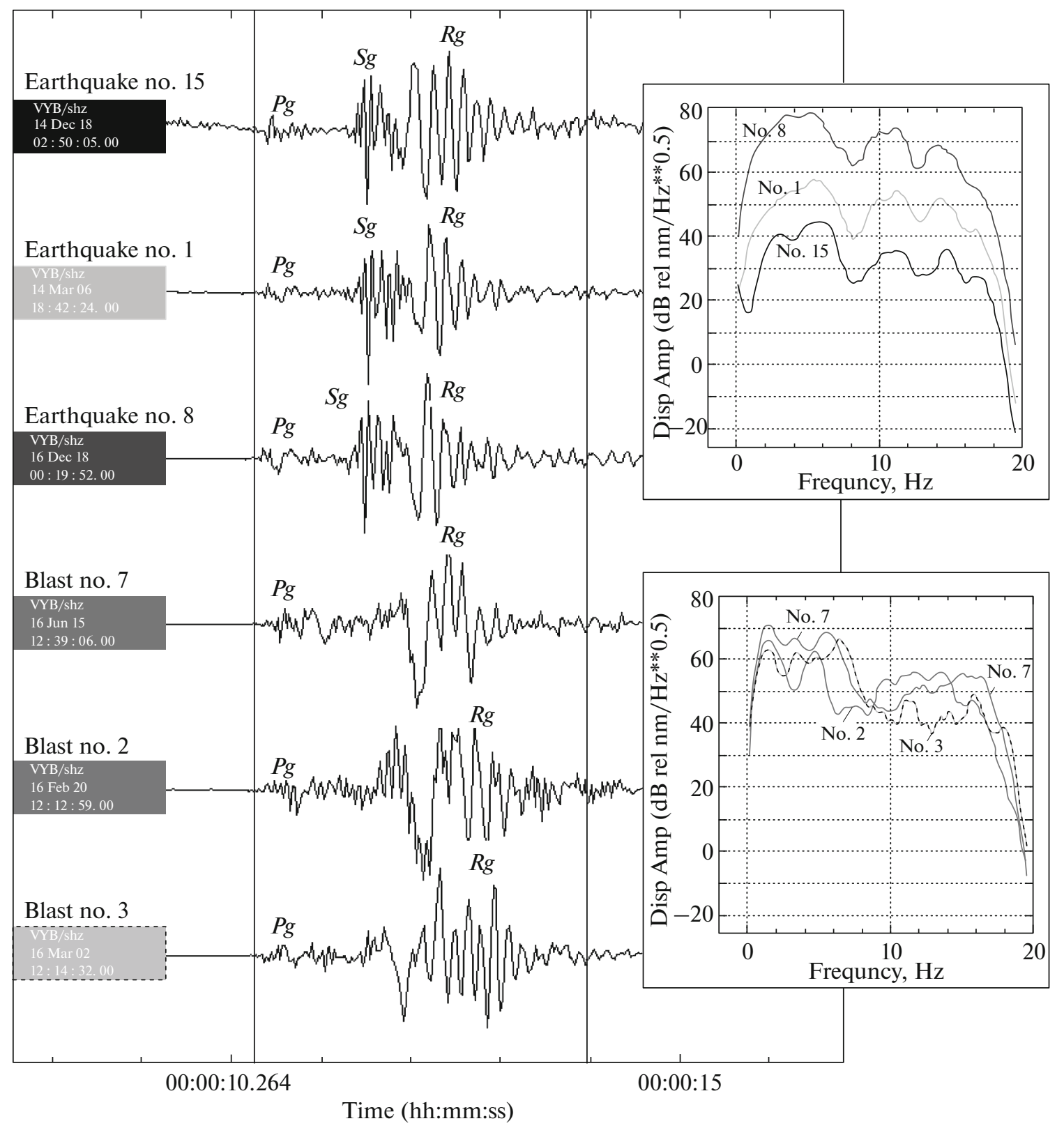

Fig. 10. Records of three earthquakes and three blasts in vertical component and identically smoothed displacement amplitude spectra. Done in Geotool program (Coyne et al., 2003).

distance also decays. The precritical reflection from the Moho boundary $S m S$ and its surface reflection $s S m S$ also smear the $R g$ signal. The $s P$ phase is quite clear both in the real and synthetic seismograms. Here, the waveforms are also best modeled by synthetic waves in the depth range of $1.5-2.5 \mathrm{~km}$.

In conclusion, the depth estimates obtained from $s P$ and $R g$ observations for the $P$ wave amplitude ratios confirm that the main event of December 18, 2016 at 00:20 occurred at a depth of $2 \pm 1 \mathrm{~km}$.

Table 5 summarizes the final results of determining the parameters of earthquakes with the estab- lished $s P-P$ travel-time difference that occurred in March 2014 (5 events), July 2016 (3 events), and December 2016 (24 events).

The sets look like swarms; i.e., they frequently occurred with a very small time interval and overlapping waveforms. The occurrence time of the events is distributed quite uniformly over several days, the magnitude interval $M_{L}$ was -0.6 to +2.1 , and for certain earthquakes, the depths and magnitudes were not determined owing to the merging of waves. Weak events with negative magnitudes were mainly recorded by the VYB station, which, first, is located in direct 


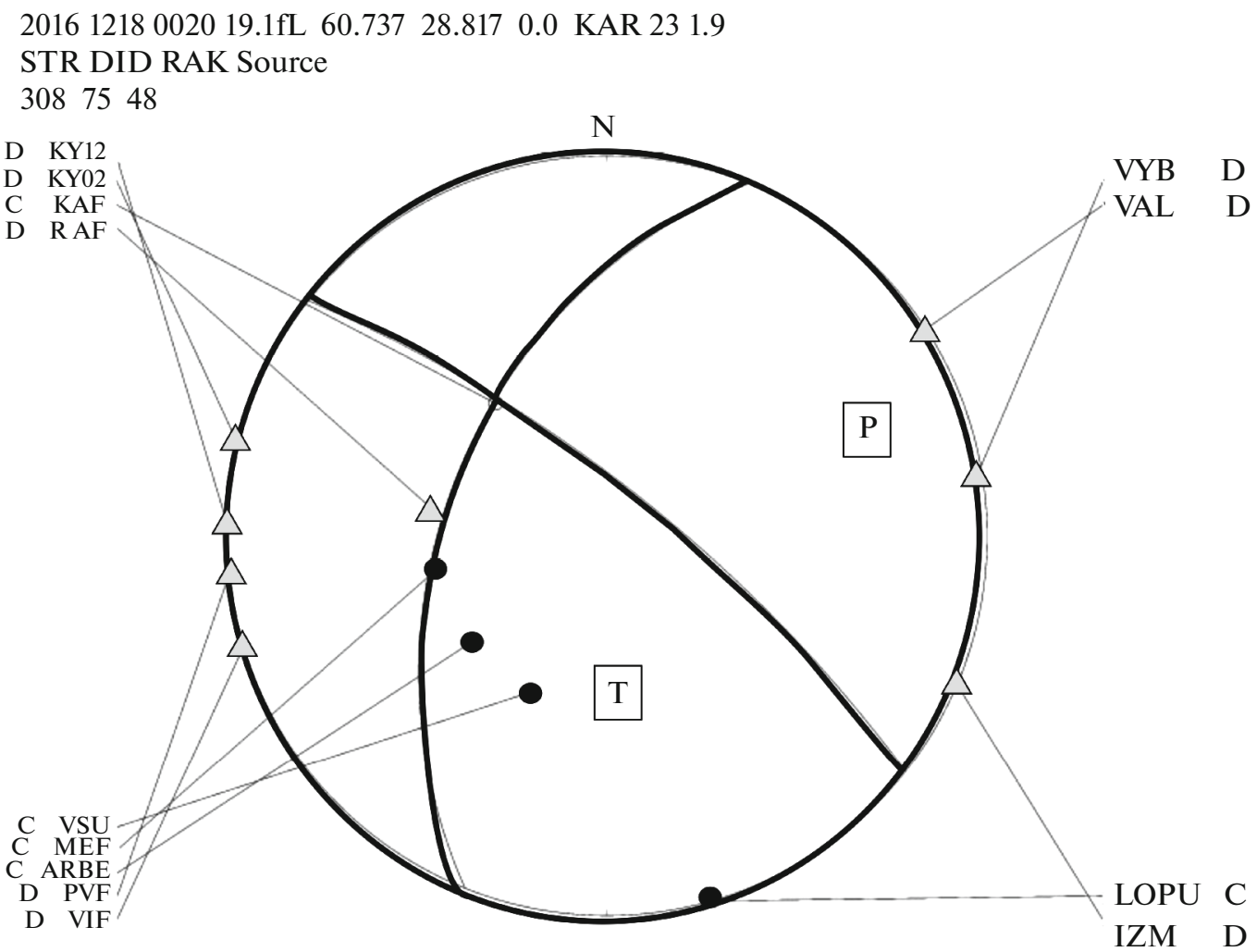

Fig. 11. Focal mechanism of earthquake on December 18, 2016, at 00:20. Employed stations are shown. P and T denote compression and extension, respectively. Constructed in SEISAN program (http://www.uib.no).

proximity to the epicentral zone $(5-8 \mathrm{~km})$, and second, has unique recording capabilities (see Fig. 1).

In the map (Fig. 13), the sets of swarmlike events form a linear zone around $4 \mathrm{~km}$ in length, extending submeridionally and passing along a possible fault through the Erkilja quarry. The middle of the zone hosts the epicenter of the strongest $\left(M_{L}=2.1\right)$ and deepest $(h=2 \mathrm{~km})$ event of December 18, 2016, at 00:20. To the north and south of it, at a distance of approximately $1 \mathrm{~km}$, several swarms are distinguished. It is interesting that the orientation of the zone on the whole does not coincide with the direction of the possible rupture plane in the focal mechanism, which allows the conclusion that the swarms could have activated shallower faulting with a different orientation. It can be assumed that the fault formed vertically.

From the geological viewpoint, a characteristic feature of the zone is the presence here of the eastern wall of the Vyborg rapakivi granite intrusion of Upper Proterozoic age, which is a thick, tabular body spanning $180 \mathrm{~km}$ from north to south and $60-130 \mathrm{~km}$ from west to east (Kiselev et al., 1997). It is essential to note that the massif is rife with material and structural inhomogeneities - the rapakivi granite itself is represented by several petrographic varieties: vyborgite, piterlite, and massive ovoid subporphyritic bodies.
The structure is broken by numerous subparallel tectonic faults, mainly to the northwest (see Fig. 13).

In some places, including in and around focal zones, there are faults and veined bodies with an orthogonal northwestern orientation with pegmatiteaplite and pure quartz compositions. It can be thought that the revealed seismic activity zones are associated with local tectonic knots. Such fault structures have been discovered within the rapakivi granite massif in areas where the above-mentioned swarms occurred in Anjalankoski and Kouvola, Finland, in 2003 and 2001, respectively. Tectonically, the rapakivi intrusion terminates farther to the northeast, in the vicinity of Kammenogorsk. The above-mentioned seismic paleodeformations have been found in this tectonic contact zone.

\section{CONCLUSIONS}

The above results of detailed studies of seismic events instrumentally recorded on the Karelian Isthmus in 2014-2016 have shown that, first, they possess a specific wave pattern differing from that of industrial blasts, and second, they are similar in manifestation to the 2003 and 2011 swarms in Finland. The events are characterized by different signs of the first arrivals of longitudinal waves in the seismograms, as a result of which it became possible to construct the focal mech- 
(a)

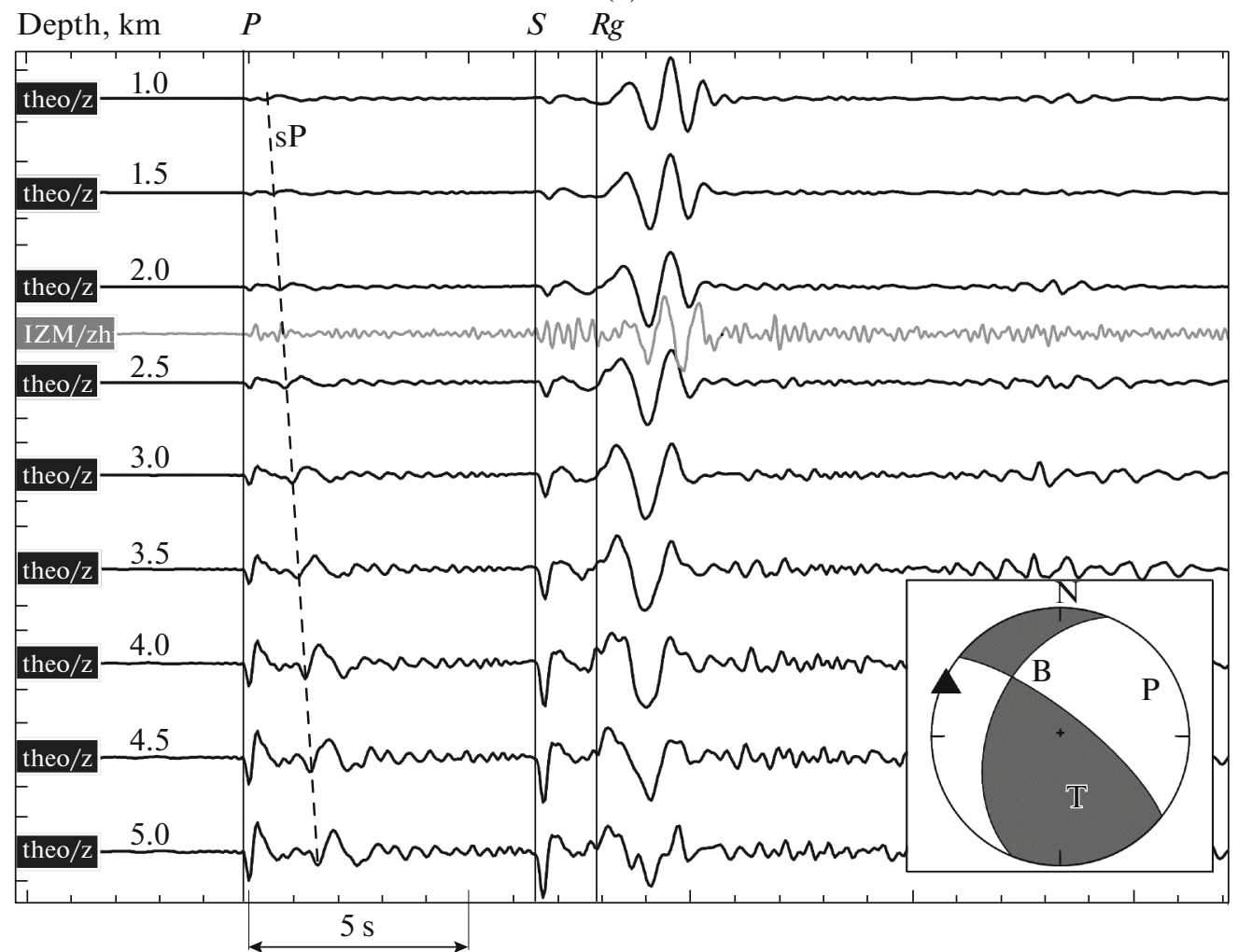

(b)

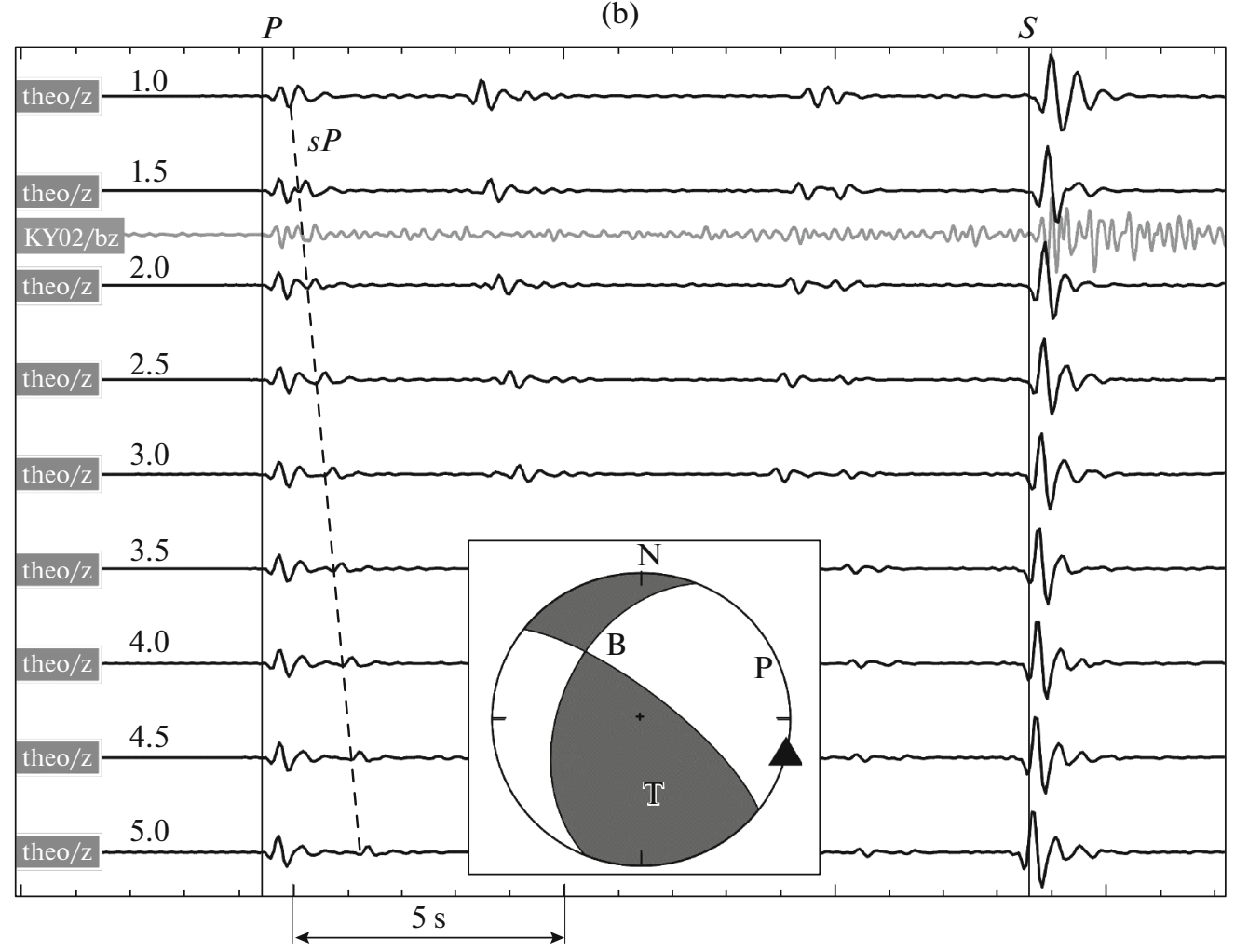

Fig. 12. Comparison of synthetic and observed seismograms of vertical component of main event at (a) IZM station and (b) KY02 station; epicentral distances are 53 and $115 \mathrm{~km}$, respectively. Numerals above synthetic traces mark source depth. Solid vertical lines show first arrivals of $P, S$, and $R g$ waves in initial seismogram; dotted lines, arrival of $s P$ in theoretical traces. Signals are normalized and filtered in $1-5 \mathrm{~Hz}$ band. Locations of stations (filled triangles) are also shown in lower hemisphere of focal mechanism diagram. 
Table 5. List of earthquakes

\begin{tabular}{|c|c|c|c|c|c|c|c|}
\hline No. & $\begin{array}{l}\text { Date, day- } \\
\text { month-year }\end{array}$ & $\begin{array}{c}\text { Time } \\
\text { hh:mm:ss }\end{array}$ & Latitude, ${ }^{\circ} \mathrm{N}$ & Latitude, ${ }^{\circ} \mathrm{E}$ & $M_{L}$ & $s P-P, \mathrm{~s}$ & $h, \mathrm{~km}$ \\
\hline 1 & 06-Mar-14 & $08: 10: 54.00$ & 60.756 & 28.841 & 0.3 & 0.3 & 0.9 \\
\hline 2 & 06-Mar-14 & 09:06:08.15 & 60.756 & 28.841 & 1.0 & 0.3 & 0.9 \\
\hline 3 & 06-Mar-14 & 09:14:08.02 & 60.756 & 28.841 & 0.1 & 0.3 & 0.9 \\
\hline 4 & 06-Mar-14 & 09:14:11.28 & 60.756 & 28.841 & 0.4 & 0.3 & 0.9 \\
\hline 5 & 06-Mar-14 & $18: 42: 32.33$ & 60.756 & 28.841 & 1.3 & 0.6 & 1.8 \\
\hline 6 & 11-Jul-16 & $01: 47: 45.96$ & 60.740 & 28.844 & 1.05 & 0.4 & 1.2 \\
\hline 7 & 11-Jul-16 & 01:49:31.04 & 60.757 & 28.841 & 1.15 & 0.4 & 1.2 \\
\hline 8 & 11-Jul-16 & 03:39:52.84 & 60.757 & 28.841 & 0.6 & 0.5 & 1.5 \\
\hline 9 & 18-Dec-16 & 00:20:19.39 & 60.750 & 28.846 & 2.1 & 0.7 & 2.0 \\
\hline 10 & 18-Dec-16 & 00:30:27.59 & 60.750 & 28.842 & 1.4 & 0.4 & 1.2 \\
\hline 11 & 18-Dec-16 & $00: 32: 36.38$ & 60.750 & 28.842 & 0.5 & 0.5 & 1.5 \\
\hline 12 & 18-Dec-16 & 00:49:12.00 & 60.750 & 28.842 & -0.3 & 0.3 & 0.9 \\
\hline 13 & 18-Dec-16 & $00: 54: 21.12$ & 60.747 & 28.842 & 0.8 & 0.4 & 1.2 \\
\hline 14 & 18-Dec-16 & 01:04:19.38 & 60.747 & 28.842 & 0.9 & 0.2 & 0.6 \\
\hline 15 & 18-Dec-16 & 01:22:57.92 & 60.747 & 28.842 & 0.5 & 0.4 & 1.2 \\
\hline 16 & 18-Dec-16 & 01:24:09.94 & 60.747 & 28.842 & -0.5 & 0.3 & 0.9 \\
\hline 17 & 18-Dec-16 & 01:29:47.06 & 60.747 & 28.842 & 0.1 & - & - \\
\hline 18 & 18-Dec-16 & 01:33:56.12 & 60.747 & 28.842 & -0.6 & - & - \\
\hline 19 & 18-Dec-16 & 01:35:19.73 & 60.747 & 28.842 & -0.2 & - & - \\
\hline 20 & 18-Dec-16 & 01:41:20.44 & 60.747 & 28.842 & -0.4 & 0.3 & 0.9 \\
\hline 21 & 18-Dec-16 & $02: 12: 15.28$ & 60.747 & 28.842 & 0.9 & 0.6 & 1.9 \\
\hline 22 & 18-Dec-16 & $02: 29: 30.65$ & 60.747 & 28.842 & -0.1 & - & - \\
\hline 23 & 18-Dec-16 & $02: 34: 54.16$ & 60.747 & 28.842 & -0.5 & - & - \\
\hline 24 & 18-Dec-16 & 02:35:13.90 & 60.735 & 28.842 & 1.3 & 0.4 & 1.2 \\
\hline 25 & 18-Dec-16 & 02:50:26.08 & 60.730 & 28.840 & 1.3 & 0.4 & 1.2 \\
\hline 26 & 18-Dec-16 & 03:21:23.37 & 60.730 & 28.840 & 0.9 & 0.3 & 0.9 \\
\hline 27 & 18-Dec-16 & 04:54:10.93 & 60.730 & 28.840 & -0.3 & 0.3 & 0.9 \\
\hline 28 & 18-Dec-16 & 05:06:02.16 & 60.730 & 28.840 & -0.5 & - & - \\
\hline 29 & 18-Dec-16 & 07:40:28.27 & 60.730 & 28.840 & -0.5 & - & - \\
\hline 30 & 18-Dec-16 & $18: 04: 23.76$ & 60.757 & 28.839 & 1.25 & 0.2 & 0.6 \\
\hline 31 & 18-Dec-16 & $20: 25: 21.49$ & 60.757 & 28.839 & -0.4 & - & - \\
\hline 32 & 18-Dec-16 & $21: 22: 30.07$ & 60.757 & 28.839 & -0.2 & - & - \\
\hline
\end{tabular}




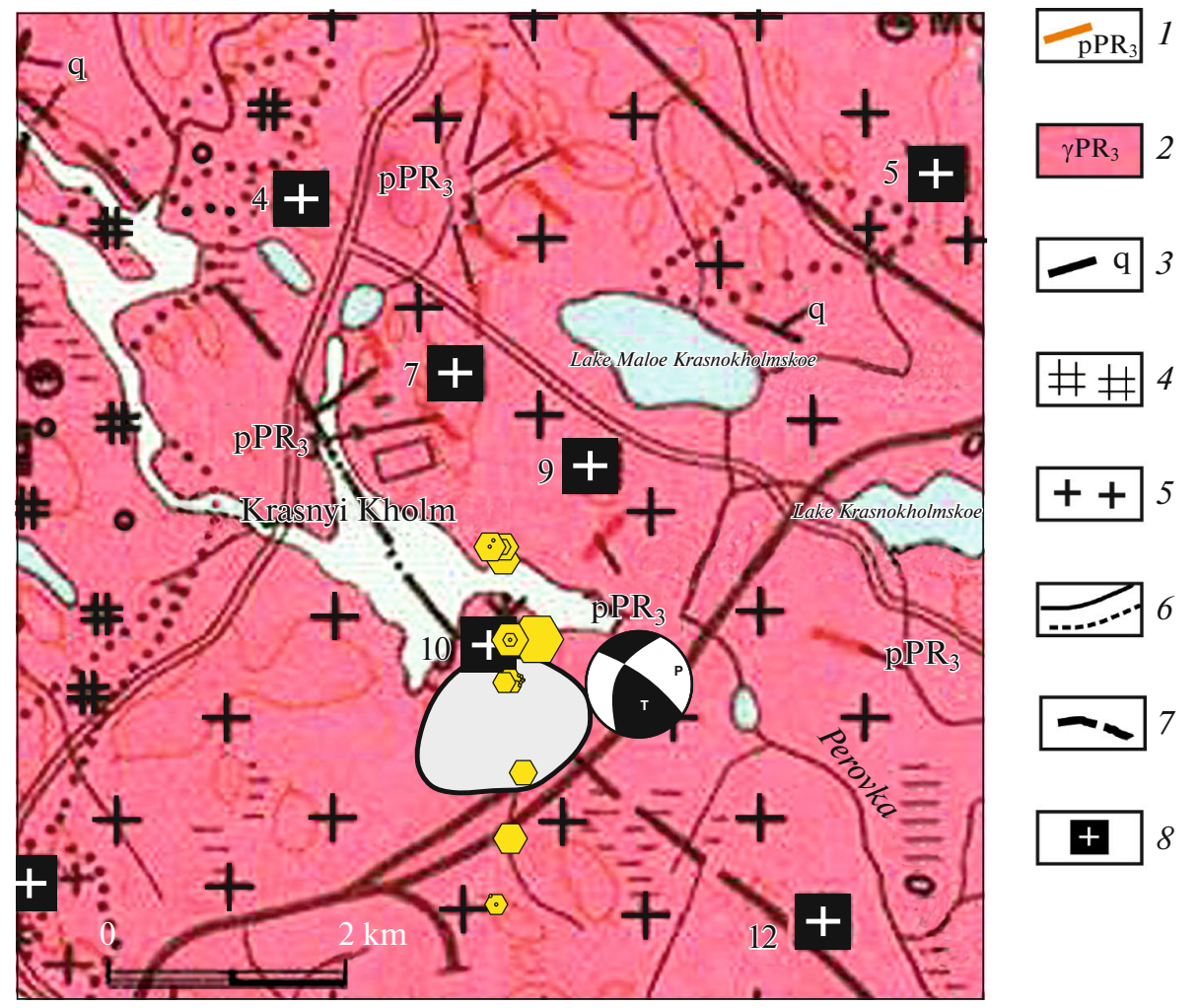

Fig. 13. Fragment of geological map of study area. Sheet P-35-XXIX, 1 : 200000 (http://www.geolkarta.ru/ list_200.php?idlist=P-35-XXIX). Arbitrary notes: (1) Late Proterozoic intrusions, veined bodies: pegmatite and aplite; (2) rapakivi granite (Vyborg massif); (3) quartz veins; (4) rapakivi granite, subporphyritic, medium-grained; (5) biotite-hornblende ovoid (vyborgite); (6) boundaries between bodies of different age and facies petrographic units of the same age, reliable and supposed; (7) tectonic margins and faults; (8) mineral deposits. Earthquake sources are marked by yellow hexagons; size of sign is proportional to $M_{L} / 1$; events with negative magnitudes are outside scale; focal mechanism is shown for strongest event of December 18 at 00:20. Gray area, approximate location of Erkilja quarry.

anism. It is quite probable that new faulting may have developed across the Erkilja quarry.

The recording of earthquake swarms with $M_{L}=$ -0.6 to +2.1 on the Karelian Isthmus points to a significant change in the stress state of this geological setting in recent years. On the one hand, there are the well-known historical earthquakes of 1870, 1902, and 1926 , but on the other hand, it is impossible to exclude the technogenic-tectonic character of this seismicity, because this region had previously never been subjected to such a strong blasting load.

\section{REFERENCES}

Aivazyan, S.A., Bukhshtaber, V.M., Enyukov, I.S., and Meshalkin, L.D., Prikladnaya statistika. Klassifikatsiya $i$ snizhenie razmernosti (Applied Statistics: Classification and Reduction of Dimensionality), Aivazyan, S.A., Ed., Moscow: Finansy i statistika, 1989, pp. 143-330.

Assinovskaya, B.A. and Verzilin, N.N., On seismic hazard in the Baltic Sea, in Izmenyayushchayasya geologicheskaya sreda: prostranstvenno-vremennye vzaimodeistviya endogennykh $i$ ekzogennykh protsessov: Materialy Mezhdunarodnoi konferentsii (Changing Geological Medium and Spatiotemporal Interactions between Endogenous and Exogenous
Processes: Proceedings of the International Conference), Kazan, Russia, 2007, Kazan: Kazan. Gos. Univ, 2007, vol. 1, pp. 210-214.

Assinovskaya, B.A. and Nikonov, A.A., Seismicity of Karelian region, in Glubinnoe stroenie $i$ seismichnost' Karelii (Deep Structure and Seismicity of Karelia), Sharov, N.V., Ed., Petrozavodsk: Karel. Nauchn. Tsentr Ross. Akad. Nauk, 2003, pp. 192-237.

Assinovskaya, B.A., Verzilin, N.N., Karpinskii, V.V., and Tronin, A.A., Seismogeological investigation of the source zone of the May 13,1902 historical earthquake on the northern coast of Lake Sukhodol'skoe, Vestn. St.-Peterb. Gos. Univ. Ser. 7: Geol. Geogr., 2010, no. 1, pp. 117-128.

Chernobay, I.P. and Gabsatarova, I.P., Source classification in the Northern Caucasus, Phys. Earth Planet. Inter. 1999, vol. 133, pp. 183-201.

Chernobye, I., Zhizhin, M., Gabsatarova, I., and Mechrushev, D., Analysis of the Near Source and Regional Seismic Records from Mine Explosions in Northern Caucasus. Discrimination between Explosions and Regional Earthquakes: Technical Report SPC-94-4088, Obninsk: Russ. Acad. Sci. Geophys. Surv., 1995.

Coyne, J., Clark, K., and Lloyd, S., IDC Documentations Geotool Software User Tutorial of July 16, 2003. 
Golstein, P., Dodge, D., Firpoand, M., and Lee, M., SAC2000: Signal processing and analysis tools for seismologists and engineers, in International Handbook of Earthquake and Engineering Seismology, Lee, W.H.K., Kanamori, H., Jennings, P.C., and Kisslinger, C., London: Academic Press, 2003, pp. 1613-1614.

IASPEI New Manual of Seismological Observatory Practice, Bormann, P., Ed., Potsdam: GeoForschungsZentrum. 2002.

Karpinskii, V.V., Munirova, L.M., Panas, N.M., and Karpinskaya, O.V., Seismological observations in Northwest Russian Federation, in Sovremennye metody obrabotki $i$ interpretatsii seismologicheskikh dannykh: Materialy XII Mezhdunarodnoi seismologicheskoi shkoly (Modern Methods of Processing and Interpreting Seismological Data: Proceedings of XII International Seismological Workshop), Malovichko, A.A., Ed., Obninsk: Edinaya Geofiz. Sluzhba Ross. Akad. Nauk, 2017, pp. 175-178.

Kennett, B.L.N., IASPEI 1991 Seismological Tables, Canberra: Bibliotech, 1991.

Kiselev, I.I., Proskuryakov, V.V., and Savanin, V.V., Geologiya $i$ poleznye iskopaemye Leningradskoi oblasti (Geology and Mineral Resources of Leningrad Oblast), St. Petersburg: Peterburgskaya kompleksnaya ekspeditsiya, 1997, pp. 132-134.

Kind, R., The reflectivity method for a buried source, $J$. Geophys., 1978, vol. 44, pp. 603-612.

Kind, R., Extensions of the reflectivity method, J. Geophys., 1979, vol. 45, pp. 373-380.
Nikonov, A.A., The Narva earthquake on January 28, 1881, in the eastern part of the Gulf of Finland, Seism. Instrum., 2011, vol. 47, no. 4, pp. 337-345.

Nikonov, A.A., Shvarev, S.V., Sim, L.A., Rodkin, M.V., Biske, Yu.S., and Marinin, A.V., Paleoseismodeformations of hard rocks in the Karelian isthmus, Dokl. Earth Sci., 2014, vol. 457, no. 2, pp. 1008-1013.

Panas, N.M. and Assinovskaya, B.A., Tectonic events in the Karelian isthmus, in Sovremennye metody obrabotki $i$ interpretatsii seismologicheskikh dannykh: Materialy XII Mezhdunarodnoi seismologicheskoi shkoly (Modern Methods of Processing and Interpreting Seismological Data: Proceedings of XII International Seismological Workshop), Malovichko, A.A., Ed., Obninsk: Edinaya Geofiz. Sluzhba Ross. Akad. Nauk, 2017, pp. 259-263.

Renquist, H., Finlands jordskalv, Fennia, 1930, vol. 54, no. 1.

Smedberg, I., Uski, M., Tiira, T., Komminaho, K., and Korja, A., Intraplate earthquake swarm in Kouvola, southeastern Finland, General Assembly European Geosciences Union 2012, Vienna, Austria, 2012, abstr. no. 8446.

Uski, M., Tiira, T., and Korja, A., and Elo, S., The 2003 earthquake swarm in Anjalankoski, south-eastern Finland, Tectonophysics, 2006, vol. 422, pp. 55-69.

Vryvy i zemletryaseniya na territorii Evropeiskoi chasti Rossii (Explosions and Earthquakes in the territory of European Part of Russia), Adushkin, V.V. and Malovichko, A.A., Eds., Moscow: GEOS, 2013.

Translated by A. Carpenter 